\title{
The Fight is Still On: An Ethical Analysis of the American Civil Liberties Union's Partisan Rhetoric in the Trump Era
}

\author{
Emily Charlotte Gerber \\ West Virginia University, ecotter@mix.wvu.edu
}

Follow this and additional works at: https://researchrepository.wvu.edu/etd

Part of the Journalism Studies Commons, Mass Communication Commons, Organizational

Communication Commons, Public Relations and Advertising Commons, and the Social Influence and

Political Communication Commons

\section{Recommended Citation}

Gerber, Emily Charlotte, "The Fight is Still On: An Ethical Analysis of the American Civil Liberties Union's Partisan Rhetoric in the Trump Era" (2020). Graduate Theses, Dissertations, and Problem Reports. 7921. https://researchrepository.wvu.edu/etd/7921

This Thesis is protected by copyright and/or related rights. It has been brought to you by the The Research Repository @ WVU with permission from the rights-holder(s). You are free to use this Thesis in any way that is permitted by the copyright and related rights legislation that applies to your use. For other uses you must obtain permission from the rights-holder(s) directly, unless additional rights are indicated by a Creative Commons license in the record and/ or on the work itself. This Thesis has been accepted for inclusion in WVU Graduate Theses, Dissertations, and Problem Reports collection by an authorized administrator of The Research Repository @ WVU. For more information, please contact researchrepository@mail.wvu.edu. 


\title{
The Fight is Still On: An Ethical Analysis of the American Civil Liberties Union's Partisan Rhetoric in the Trump Era
}

\author{
Emily Gerber \\ Thesis submitted to the Reed College of Media \\ at West Virginia University \\ in partial fulfillment of the requirements for the degree of \\ Master of Science in Journalism \\ Reed College of Media \\ Steve Urbanski, Ph.D., Chair \\ Diana Martinelli, Ph.D. \\ Elizabeth Oppe, Ph.D. \\ Kristi Wood-Turner, Ed.D.
}

Morgantown, West Virginia

2020

Keywords: President Donald Trump, American Civil Liberties Union, ACLU, nonprofit ethics, nonpartisan, partisan rhetoric, OPR theory, POPR theory

Copyright 2020 Emily Gerber 


\section{ABSTRACT \\ The Fight is Still On: An Ethical Analysis of the American Civil Liberties Union's Partisan Rhetoric in the Trump Era}

\section{Emily Gerber}

The 2016 U.S. presidential election of Donald Trump generated a newfound surge in political advocacy that greatly benefitted certain nonprofits and grassroots organizations. One of these organizations was the American Civil Liberties Union, a nonpartisan nonprofit dedicated to protecting and defending civil liberties and rights in the U.S. The ACLU received an unprecedented number of donations following Election Day and has since pursued an aggressive campaign against President Donald Trump.

In order to explore this phenomenon, this thesis analyzed the ACLU's rhetoric between Presidents George W. Bush and Donald Trump (both Republicans) and between Presidents Barack Obama (Democrat) and Donald Trump (Republican) to see if their rhetoric changed according to the president's political party affiliation. This study utilized qualitative content analysis to not only count the number of times the president was mentioned negatively but to also analyze the meaning behind their rhetoric.

While the ACLU prides itself on being nonpartisan, it was found that the organization has been tougher on Republican administrations in the past two decades both in how often they use negative rhetoric toward a president and their aggressive diction. The election of President Donald Trump, however, has provided a stark example of the organization's change in rhetoric toward presidents over time. The ACLU has both drastically increased the how often they talk about the president and how often they use negative rhetoric against him.

This thesis then explored the ethics behind their decision to pursue an aggressive, arguably partisan campaign against the President, taking into account how this affects the ACLU's stakeholders. These groups include their donors/dues-paying members, those they represent in court, the American public and the U.S. government.

This thesis contributes to the growing body of knowledge surrounding the Trump presidency and its effects on the American landscape. In particular, this study adds to our understanding of how a political, nonpartisan nonprofit changed their rhetoric toward a president whose policies go against their mission statement. 


\section{ACKNOWLEDGEMENTS}

First and foremost, I want to highlight the members of my committee for their support and for sharing their expertise in ethics, public relations, nonprofits and politics. I want to thank my chair, Dr. Steve Urbanski, for all of his assistance navigating the program, taking the time to discuss careers following graduation and for all of the political and ethical discussions we had on the mass communications field today. Our conversations made me think about the world more critically, and my thesis greatly benefitted from this point of view.

I want to thank Dean Diana Martinelli for her assistance writing this thesis and for inspiring me with her own research in political communications. Her rigorous research methods course helped me better understand how to write a thesis and hone in on a topic. I am grateful for her expertise in the area and eye for detail.

Both Drs. Elizabeth Oppe and Kristi Wood-Turner have supported my studies and growth as a person since my undergraduate days, and I am grateful they were willing to help me yet again on this project. I have learned so much from Dr. Oppe about using public relations for social good through our discussions and her courses, including a service-learning course in Jamaica. Dr. Oppe's work has been an inspiration for me, and I am grateful that she could bring her perspective to this thesis.

As an undergraduate student, I had the pleasure of working with Dr. Wood-Turner as a resident assistant where she helped me grow as a student and encouraged me to find my passion. In her role as the Director of the WVU Center for Service and Learning, Dr. Wood-Turner has taught me so much about the nonprofit sector over the years. I want to thank Dr. Wood-Turner for her unique expertise on my committee and for her continued support.

I would also like to thank my parents, Joel and Annette Cotter, for their love and support. They have always gone out of their way to help me achieve my goals. Thank you to Lindsey Kovacs and Kristen Newland for their friendship and for sharing their own academic experiences with me. Last but certainly not least, I would like to thank my husband, Bradley, for always supporting my academic career no matter where that took us. Thank you for your sympathetic ear, words of encouragement and kind heart. 


\section{TABLE OF CONTENTS}

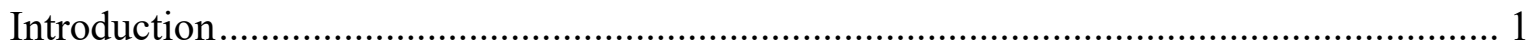

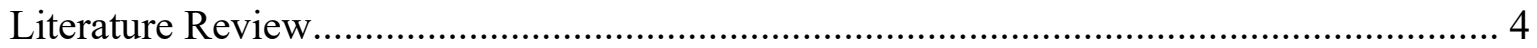

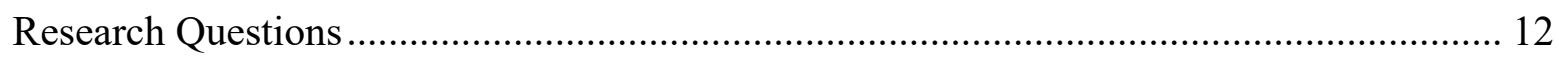

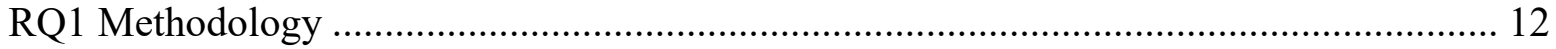

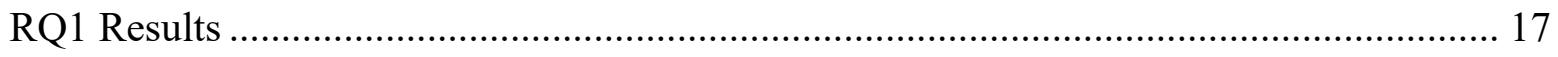

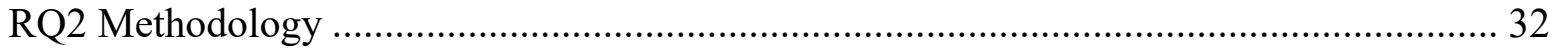

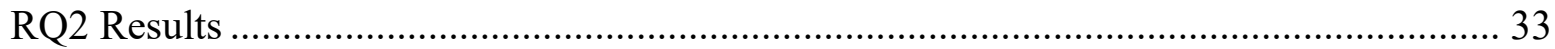

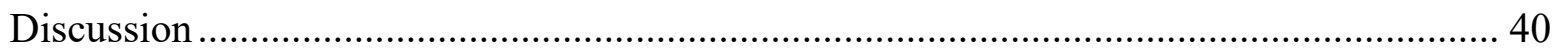

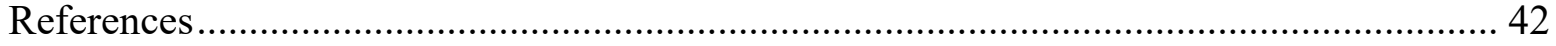

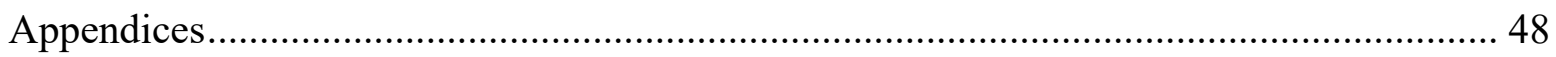


While we cannot claim to have predicted — or frankly even imagined — a Trump presidency, we came on board more than 15 years ago knowing that the ACLU needed a plan for smart and strategic growth in order to confront the inevitable civil liberties crises ahead. Within the first week of Trump's inauguration, we had one, and we were prepared (p. 25).

-Anthony D. Romero, ACLU Executive Director and Geri E. Rozanski, Director of the ACLU Affiliate Support \& Nationwide Initiatives (2017)

The American Civil Liberties Union is both famous for representing groups like the LGBTQ+ community and notorious for representing organizations like the Ku Klux Klan in court (Wilkins, 1995). While many Americans consider the ACLU to be a liberal organization, the ACLU identifies itself as a nonpartisan nonprofit, and their work has typically reflected that mentality. Since the 2016 presidential election, however, the ACLU has deliberately attacked President Donald Trump and members of his administration through their public relations efforts.

The ACLU executive director, Anthony D. Romero, has been one of the more vocal critics of Trump and his administration. Romero has penned Trump a "one man Constitutional crisis," citing the various domestic and international laws Trump's policies would violate. These include the First, Fourth, Fifth and Eighth Amendments, The Privacy Act and The Convention Against Torture, among others (Romero, 2016). The ACLU homepage features the words "the fight is still on" over a picture of the president (ACLU, n.d.), and the organization's various social media accounts have posted personal attacks against him and his administration.

The Trump presidency has sparked a new era in politics, and the American Civil Liberties Union has greatly benefitted from this newfound surge in political advocacy. The organization received an unprecedented number of donations following the 2016 election, raising \$2.4 million the day after Election Day, which led to their website crashing (Holden, 2016). According to Liam Stack (2017) of The New York Times, the organization further raised \$24 
million online in the three-day period following the implementation of Trump's Executive Order that barred people from select Middle Eastern countries from entering the U.S. For reference, Stack notes the organization raised only $\$ 3.5$ million in online donations in all of 2015. At this time, financial data is unavailable for donations to the ACLU following the 2020 presidential election. Unlike 2016, however, the ACLU and the media's silence on donations likely shows that they did not receive a similar surge in donations again.

While 2017 was the height of donations to the ACLU, they maintained a strong, steady stream of donations in the years following. In Fiscal Year 2016 (when President Trump won the presidency late in the year), the organization (including its affiliates and foundation) earned \$106,628,381 in grants and contributions. In 2017 (when President Trump enacted the E.O. mentioned previously), they earned $\$ 274,104,575$; in 2018 , they earned $\$ 250,059,321$; and in 2019, they earned \$262,339,542 (ACLU Annual Reports for 2017, 2018 and 2019).

This situation is certainly not unique to the ACLU. Planned Parenthood also received an unprecedented number of donations, and the Council on American-Islamic Relations (CAIR) had a surge in their number of volunteers (Chandler, 2016). Infotainment celebrity and host of Last Week Tonight's John Oliver directed his viewers to donate to progressive organizations like the Trevor Project, the NAACP Legal Defense Fund and the Center for Reproductive Rights following the 2016 election (Garber, 2016). EMILY's List, meaning “Early Money Is Like Yeast," saw a massive increase in the number of women planning on running for office (from 920 the previous year to 16,000) (EMILY's List, n.d.; Cramer, 2017). These specific organizations, however, tend to be left leaning and do not paint the whole picture of the Trump presidency. Before the election, many prominent Republicans, including former First Lady Barbara Bush, former Secretary of State Colin Powell and former Republican presidential 
candidate Mitt Romney, vowed to either vote for Hillary Clinton or write in another candidate due to their distaste for Trump (Johnstone, 2016; Graham, 2016).

One of the most important terms to come up again and again in the Trump era is the word unprecedented. Liberal organizations have received unprecedented numbers of donations and volunteer hours. An unprecedented number of Republicans spoke out against Trump's nomination and election. Unprecedented numbers of women are now planning on running for office. While this provides a justification for why these organizations are pursuing aggressive campaigns against President Trump and his administration, that does not necessarily make it the ethical choice for a nonpartisan organization, such as the ACLU.

The ACLU has been quite forward with their views on this ethical issue and how they are striving to maintain a balance while being a nonpartisan nonprofit in this era. In ACLU Executive Director Romero's (2017) article, What Does Nonpartisanship Look Like in the Age of Trump?, he explains why they are taking on this administration so wholeheartedly and that issues that are not necessarily civil liberties infringements themselves can still lead to attacks on our civil liberties as a whole. In the article, Romero cites the ACLU's tough stances against democratic Presidents Obama and Clinton when they too attacked civil liberties, and he even cited a New York Times article the ACLU published with Obama morphing into President George W. Bush. (The article, however, did not mention specific examples of them going against the Bush administration.)

Therefore, this thesis seeks to better understand mass communications in the Trump era through the lens of a political, yet self-described nonpartisan, nonprofit. Specifically, it seeks to better understand the ACLU's rhetoric about various White House administrations at key points in time, including presidential election periods, the first months in office following inaugurations 
and during important civil liberties cases involving the ACLU. Then the ethicality behind its decision to pursue an aggressive, partisan campaign against President Trump and his administration will be examined.

\section{LITERATURE REVIEW}

The ACLU fights to protect a wide variety of civil liberties issues, including immigration, free speech, reproductive freedom, LGBTQ+ rights and religious liberties, among others (ACLU, n.d.), but their roots were in protecting Americans during the Red Scare of the 1920 s in the postWWI United States. The Russian Revolution frightened many Americans, and the U.S. government implemented extreme tactics in an attempt to stop the spread of communism to North America. Under U.S. Attorney General Mitchell Palmer, the government implemented the Palmer Raids to deport those they deemed radicals. In the wake of these illegal actions taken by the U.S. government, the ACLU was founded to stand up for Americans, the Constitution and basic civil liberties (ACLU, n.d.; History, n.d.).

The organization is nonpartisan, and because of this, they have represented a wide variety of groups in court. As a nonpartisan organization, the ACLU is not without its critics. Many Democrats and left-leaning individuals have come out against the organization's actions (e.g., Neuborne's (2012) critique of the ACLU's pro-Citizens United stance); however, the majority of criticism against the ACLU has come from the conservative end of the spectrum. Some conservatives have claimed that the organization's views are "imperialistic" (Holloway, 2015), while right-wing news anchor, Bill O’Reilly, even claimed that the ACLU is a "terrorist organization" (Nyren, 2017). Canaparo (2020) posted a commentary on the conservative nonprofit, The Heritage Foundation's website stating that the ACLU has drifted from their 
original nonpartisan stance and "retreated from its principles when they clash with trendy leftwing priorities."

More recently, the ACLU (n.d.) published data about their donors, showing an overwhelming support for the Democratic Party. They noted that their supporters donated $\$ 463$ million to "Democratic candidates, committees and PACs" while only donating \$19 million to Republican groups and candidates during the 2020 election. Additionally, they found that their donors largely supported the Democratic presidential candidate, Joe Biden, with a fifth of all donations to his campaign coming from ACLU supporters. Their point to this article was that members of the ACLU are important and involved in the political process outside of the ACLU; however, it is also a strong demonstration of the support they have from Democrats.

\section{Civil Liberties in the Trump Era}

President Trump's contentious nature, both as a politician and the controversial way in which he won the presidency in 2016 (i.e., winning the electoral vote but losing the popular vote by nearly 3 million votes (CNN, n.d.), portend a growing area of study within various disciplines, including communications, history, political science, business and public administration.

There are some notable researchers laying the groundwork for this emerging subfield, particularly with regard to how the Trump presidency is affecting civil liberties. For example, Nguyen and Kebede (2017) studied how President Trump has impacted the academic sector. Due to the timing of the study, the authors focused on how his rhetoric about the Deferred Action for Childhood Arrivals (DACA) policy and school choice might negatively affect immigrant students in the U.S. rather than his actual policies implemented later. 
Multiple studies have focused on Trump's impact on the Latinx community. Gantt Shafer (2017) performed a thematic analysis on the impact on this population using political correctness as a lens of study, and she found that Trump's rhetoric and actions largely contributed to the current racism toward this minority group in the U.S. Additionally, Newman, Shah and Collingwood (2018) were particularly interested in the relationship between proximity to Latinx populations and the likelihood of supporting Trump in the 2016 election. This article is important because of its methodology; the researchers looked at support for Trump over time, including the time prior to running for president, when he announced his candidacy (which they mention includes his infamous quip about Mexico sending drugs, crime and rapists) and his announcement of building a wall along the U.S.-Mexico border.

These examples highlight how Trump has impacted the American landscape; however, little is written about organizational responses to his rhetoric and actions. Pyle, Linvill and Gennett (2017) are a notable exception, as the authors analyzed how American academic institutions publicly responded to President Trump's Executive Order barring those from select Middle Eastern countries from entering the U.S. (also called the Muslim Ban).

As the Trump presidency is a growing field of study, analyses on how he has affected or will affect the nonprofit sector are growing, too. Abramson and Salamon (2016), two of the leading scholars in the nonprofit-public administration field, wrote a social commentary in which they discussed some of the impending difficulties for the sector, including tax cuts, spending cuts and regulatory changes.

Some of the articles written about the nonprofit sector in the Trump era focus on the increase in donations and civic participation following the 2016 election. Lemothe and Levastida (2020) researched whether the surge sustained over time, noting that "none of the organizations 
that experienced an initial surge completely lost their increased support during the post-election periods" (p. 15).

Conklin and Foshee (2019) analyzed donations to liberal and conservative organizations following the past four presidential elections and found that there was not a consistent pattern in donations over time. Following the 2004 election where President Bush won, liberal nonprofits had a $40.5 \%$ donation surge and conservative nonprofits had a $4.3 \%$ one. During the 2008 election where President Obama won, liberal nonprofits had only a small increase of 4\% and conservative nonprofits had a 12.1\% one. In 2012 when President Obama won reelection, donations to liberal nonprofits actually decreased $11.3 \%$, and conservative nonprofits saw a surge of $23.2 \%$. The big change, however, came after Donald Trump won the presidency in 2016: liberal nonprofits had a 155.4\% increase in donations and conservative groups received a decrease of $8.7 \%$.

\section{Political Public Relations}

Researchers have long studied the historical roots of the intersection of politics and communications, beginning with the Ancient Greeks (Kiousis \& Strömbäck, 2014). This is an important topic for a variety of political stakeholders, including elected officials, candidates, campaign staffs, bureaucrats and, indeed, the political nonprofit sector.

Perhaps one of the most studied areas in the political public relations field is negative campaign advertising, and there is no definitive consensus on whether the method is effective or harmful. Freedman and Goldstein (1999) found that negative campaign advertisements did not hinder voter turnout, and Martin (2004) found that they actually increased voter mobilization. While these articles focus on the effects on voter turnout, understanding how negative political advertisements and public relations affect the general public are important for this study because 
the ACLU is employing this same tactic. Rather than attempting to persuade voters, per se, the organization is using negative advertisements and public relations to gain donations and enroll new members. It is important to note that negative advertisements from the nonprofit sector do not necessarily produce the same results as political campaigns above, as trust in a nonprofit's word compared to politician's and/or public perceptions about the sector's role may come into play, too.

Another relevant topic is that of the partisan—nonpartisan dichotomy. Multiple studies have conducted research on the effects of partisan rhetoric; however, they have largely focused on how partisanship affects voters (Gant \& Luttbeg, 1987) and if the news has a partisan slant (Morris \& Francia, 2010). Panagopoulos (2008) studied the effect partisan versus nonpartisan rhetoric had on voter turnout and found that there was no significant difference between the two as a whole; however, he did find a difference between Democrats and Republicans. Democrats were more likely to respond to the nonpartisan message while Republicans were more likely to respond to the partisan one. This is an important distinction because while the ACLU is a nonpartisan organization, they have received more and harsher criticism from the conservative end of the spectrum.

Similar to studies of negative advertisements, little research has been conducted on how nonprofits have used partisan-nonpartisan rhetoric and their effects on the general public. The majority of research on these two topics seeks to understand the voter and how political candidates can persuade them.

Organization-Public Relationships Theory

While many Organization-Public Relationships studies have focused on the private sector, a growing number of studies have been analyzing relationships among nonprofits 
(O’Neil, 2007; Sisson, 2017; Harrison, et al., 2017). Compared to private companies, nonprofits have a diverse set of publics with which they maintain healthy relationships: volunteers, donors, their clients and the government (if the nonprofit is registered with the IRS). They may also have other relevant publics depending on their organization's mission (e.g., advocacy organizations may also need to maintain relationships with voters).

The nonprofit sector serves a unique purpose in the United States, filling the gaps where government and private companies cannot help. Government Failure Theory argues that the nonprofit sector exists to "fill in the niches left unserved by governmental action" (Young, 2012, citing Hansmann, 1987). Young also cites Douglas' (1983) argument that there are five factors that contribute to this demand on nonprofits: 1) the categorical constraint (the government must produce a uniform amount of goods for the population, and nonprofits can meet the requirements of those whom need something outside of the norm); 2) the majoritarian constraint (the government will do what is most asked for); 3) the time horizon constraint (elected officials often have short-term jobs and short-term policies; nonprofits can provide goods and services over a longer period of time); 4) the knowledge constraint (government bureaucracy can get in the way of efficiently providing goods and services to their constituents); and 5) the size constraint (because the government is large and often difficult to interact with, nonprofits provide an easily accessible way for people to get involved).

This is an important distinction for the nonprofit sector; their publics are not simply people whom they want to help or share similar ideologies with - they are also filling in for the government when they cannot or will not provide goods and services to their publics. This is increasingly important in an era of conservative politics attacking the size and scope of government. Coming to a head with the Tea Party movement, conservatives have argued that the 
size of government is too big and hurts their personal liberties (Pew Research Center, 2010).

Thus, when politicians like President Trump say they are going to limit what government will do for their constituents, it not only affects the ACLU's direct publics but the sector as a whole.

In politics, relationships among political parties and their various publics are paramount. Seltzer and Zhang (2010) found that the amount of time one identifies as a member of a political party and interpersonal trust were large factors of political organization-public relationships (POPRs), and Sweetser, English and Fernandes (2015) expanded their work to include how Super PACs use the POPR theory.

Bowen, Hung-Baesecke and Chen (2016) argued that ethics is a precursor to the OPR model's success in practice because truly positive relationships can only form when all parties have this ethical basis. The effectiveness of trust is particularly influenced by this ethical foundation. The authors argue that ethics has often been an assumption in OPR studies (or left out entirely); however, ethics should be seen as a foundational step and an "explicit variable" to successful OPR (p. 2). Legality vs. Ethicality

Bowen, Hung-Baesecke and Chen's work is relevant to this study where the ACLU's ethics with regard to the OPR model will be discussed; however, organizations wishing to use political communication must keep the potential legal ramifications in mind, too. Public relations communication has often been defined as commercial speech, which is granted less First Amendment protection than other forms of speech. An organization's communication, rather than simply what they are doing, can also cause a lawsuit (Myers \& Lariscy, 2013). Legal and ethical implications are important in this era where trust (one of the basic tenets of OPR/POPR theory mentioned above) in institutions is low: The Pew Research Center (2020) found that only 
20 percent of Americans trust the federal government (with Republicans at 28 percent and Democrats at 12 percent). This is also reflected on a global scale: the Edelman Trust Barometer (2020) found that governments, NGOs, businesses and the media are not generally trusted. Particularly, none of these groups were rated as both ethical and competent, with NGOs labeled as ethical but not competent, businesses as competent but not ethical, and the media and government as neither ethical nor competent.

It is also important to note that the ACLU has two separate organizational nonprofit entities registered with the IRS (known as a tandem structure): a 501(c)(4) and a 501(c)(3) status (Gorovitz, 2017). The 501(c)(4) organization is their main entity, and as a 501(c)(4), they are legally allowed to perform political lobbying. Their 501(c)(3) entity is the ACLU Foundation, which is limited in its ability to affect politics. Donations to the ACLU Foundation are taxdeductible; however, donations to their main political entity are not (ACLU Pennsylvania, n.d.). There are multiple rules and guidelines a nonprofit must follow to meet these requirements legally (e.g., Adler \& Colvin, n.d.); however, this structure is not unique to the ACLU. Other political nonprofits have taken advantage of this arrangement, such as the Sierra Club (Sierra Club Foundation, n.d.).

As an organization of lawyers, it makes sense that their work would follow the strict legal guidelines outlined by the IRS and legal precedent. While they are a nonpartisan nonprofit pursuing what is arguably a partisan public relations campaign, they are still within their rights as a 501(c)(4) organization. Thus, the question at hand is not whether the ACLU's new campaign is legal but rather if it is ethical.

This thesis seeks to better understand the phenomenon of mass communications in the Trump era through the lens of this political, yet nonpartisan nonprofit. By analyzing the ACLU's 
public relations rhetoric both over time and during the current White House administration, this paper adds to the growing body of literature surrounding the Trump Presidency. Additionally, this paper contributes to the political public relations and nonprofit communications fields by further analyzing the practical impacts and ethicality of partisan rhetoric in the nonprofit sector.

\section{RESEARCH QUESTIONS}

Studies on the Trump presidency have largely focused on his impact on the greater American landscape; however, relatively few studies have yet to analyze organizational responses to his rhetoric and policies. While news organizations have largely focused on liberal nonprofit responses (such as EMILY's List or She Should Run), the nonpartisan, yet political, part of the sector has yet to be explored. In order to better understand this unique subgroup, this study seeks to answer the following questions:

RQ1: How has the ACLU changed its partisan rhetoric toward political figures over the years, if at all?

RQ2: (a) Is it ethical for a nonpartisan nonprofit organization to use partisan language against an individual rather than his or her policies and executive orders?

RQ2: (b) How does partisanship affect the various ACLU stakeholders?

\section{RQ1 METHODOLOGY}

To best answer RQ1 above, a qualitative content analysis was performed to better understand both how the organization is currently engaging in partisan rhetoric and how it has done so in the past by analyzing the ACLU's homepages. Qualitative content analysis shares many similarities with its quantitative counterpart; however, this method uses a coding frame and concentrates on "meaning and interpretation of symbolic material" and "the importance of context in determining meaning" (Schreier, 2014, p. 5). The homepage was chosen as the unit of analysis because it shows the organization's priorities at that point in time. Since the homepage 
is owned and managed by the organization (opposed to journalistic articles), all images, headlines, articles, etc. are written the way they want, thus showing their intentions and priorities as an organization.

While this study largely employed open coding to find meaning in the ACLU's rhetoric, the following codes were analyzed for each document to see which civil liberties the ACLU was referring to when speaking negatively about the president: (1) abortion, (2) children's rights, (3) death penalty/capital punishment, (4) euthanasia, (5) free speech, (6) government surveillance, (7) gun rights, (8) healthcare, (9) immigration, (10) incarceration and/or police issues, (11) military, (12) Native American rights, (13) press, (14) privacy, (15) property rights, (16) race relations, (17) religion, (18) right to assemble/protesting, (19) right to due process, (20) right to marry/LGBTQ+ rights, (21) right to vote/voter suppression, (22) terrorism, (23) torture, (24) transgender rights, (25) women's rights, gender rights or feminism and (26) other. The other category could include civil rights not listed in these codes, stating the president is bad for civil liberties in a general sense or other examples of the ACLU attacking the president without mentioning civil liberties at all.

Similar to Newman, Shah and Collingwood (2018), this study was temporal in nature, reviewing the ACLU's homepage at certain key points in history (i.e., times of campaigning prior to presidential elections, the times following inaugurations and during major civil liberties cases against the White House). As Morris and Francia (2010) note, one of the main issues in analyzing partisan bias throughout history is "that the situations parties or leaders must tackle are unique" over time; presidents in various eras face different problems regarding the economy, war and current affairs. Because of this, analyzing the ACLU's rhetoric in certain points in history and when they've sued the U.S. government provides a helpful baseline (p. 836). 
This analysis was conducted using the Wayback Machine software, a web-based archive of various websites, including the ACLU's homepage. This allowed for an accurate representation of how the ACLU has responded to similar situations throughout history. The Wayback Machine software has archives of the ACLU's homepage since 1996; however, there are limited "snapshots" of the organization's homepage during this time. The Wayback Machine starts having a sufficient sample of snapshots during President George W. Bush's first term and has an even better sample starting in his second term; therefore, this study analyzed the organization's homepages from 2000 (the year President Bush won his first term) to 2017 (during President Trump's term). The following months were analyzed:

- Final campaigning months of U.S. presidential election years (i.e., SeptemberNovember 2000, 2004, 2008, 2012 and 2016)

- The months following presidential inaugurations (i.e., February-April 2001, 2005, 2009, 2013 and 2017)

- Various points when the ACLU has sued the U.S. government within these presidencies

Appendix A outlines these specific dates and how many daily snapshots on the Wayback Machine were available.

The months prior to Election Day and the months following presidential inaugurations were chosen to see if there is a difference between the ACLU's responses to campaign rhetoric (e.g., what a candidate says he or she will do if they win) versus their actual policies once elected. Additionally, the key points in history when the ACLU has sued the U.S. government over civil liberties issues were analyzed. Specifically, this study examined the differences between the ACLU's rhetoric toward President Trump (a Republican) with President Barack 
Obama (a Democrat) to see if they spoke of the two parties differently. Additionally, it also examined the differences in rhetoric toward President Bush and President Trump (both Republicans) to see if there was a difference in how they spoke of Republican administrations over the past two decades. The three cases outlined below were chosen because of their prominence in the news and the similar length of time for each lawsuit.

- ACLU v. NSA, 2007: Following the September 11, 2001 attacks on the U.S., the Bush Administration developed the Terrorist Surveillance Program through the National Security Agency. The TSP was used to observe Americans in communication with people in other countries if the NSA had a "reasonable basis" that they were connected with a terrorist organization (ACLU v. NSA, 2007). The court ruled that there was not enough evidence to prove that the program was targeting any one individual, and they ruled in favor of the NSA. The ACLU later tried to appeal the decision to the Supreme Court; however, it was denied a hearing (ACLU, n.d.).

- R.I.L-R V. Johnson, 2015: During the Obama administration, the U.S. saw a surge in families seeking asylum in the United States from Central America. While the U.S. government generally allowed families in these dire situations to be released while they awaited their hearing, the Department of Homeland Security developed an "aggressive deterrence strategy," meaning the families were not released to dissuade others from entering the U.S. illegally, too (R.I.L-R v. Johnson, 2015). The ACLU represented these families against Secretary of Homeland Security, Jeh Johnson, claiming the U.S. was breaking federal immigration law and the Fifth Amendment (ACLU, n.d.). 
- Darweesh v. Trump, 2017: President Trump implemented an executive order called Protecting the Nation from Foreign Terrorist Entry into the United States in 2017. This EO prevented people from various Middle Eastern countries from entering the U.S. and was popularly called the "Muslim Ban." The ACLU has been involved with more than 10 cases against the U.S. government with regard to this EO (Darweesh v. Trump, 2017; IRAP v. Trump, 2017; ACLU, 2017).

Because of the large amounts of data provided by the Wayback Machine, constructed random sampling was used to effectively analyze it. For the election-year months (i.e., September-November 2000, 2004, 2008, 2012 and 2016) and inauguration-year months (i.e., February-April 2001, 2005, 2009, 2013 and 2017), the first full week of every month was analyzed. On occasion, the Wayback Machine had multiple snapshots on a given day. For these, only the first snapshot was analyzed. For the time periods when the ACLU has sued the U.S. government, the following constructed timeframes were analyzed: every Monday and Tuesday in January, every Wednesday and Thursday in February, every Friday and Saturday in March and so forth through December. This is consistent with how others have used constructive sampling (e.g., Martinelli \& Mucciarone, 2007).

A codebook is provided in Appendix B and the coding form is provided in Appendix C. Due to the ACLU's work solely in the United States, codes were reflective of the two major American parties: the Democrats and Republicans. This is consistent with the timeframe to be analyzed, as only Democratic and Republican administrations have been in power since 2000 in the U.S.

Some have operationalized the term partisan as pro- or anti-Democrat/liberal and pro- or anti-Republican/conservative (e.g., Panagopoulos, 2008), and Morris and Francia (2010) further 
operationalized negativity as "critical of the attributes, statements, or policies of a political figure, party, ideology, or another political entity" (p. 848). Greene (2002) has been critical of these simplified definitions for the multifaceted term partisan; however, he was criticizing the definition from an attitudinal perspective (i.e., how can one accurately define one's views as partisan or nonpartisan) rather than a rhetorical one. Because the ACLU is an organization, not a human with a multitude of beliefs and viewpoints, the pro- or anti-Democrat/liberal and pro- or anti-Republican/conservative definitions are appropriate. The codebook and coding form are reflective of this definition.

To ensure reliable results, a second coder was trained and analyzed 35 percent $(n=256)$ of the sample at the beginning of the study to ensure initial intercoder reliability. Across all questions, ICR ranged from a low of 0.663 to a high of 0.928 , with a $p$ value of 0.00 . Two of the five questions did not reach high enough levels of agreement ( 0.7 or higher) and thus were not included in analysis. (ICR and $p$ values for each question are included in Appendix D.)

\section{RQ1 RESULTS}

For the documents analyzed during the Bush presidency, the ACLU referenced President Bush 23 out of 52 days (44.23\%), and he was referenced an average of 0.44 times per day. Similarly, for the documents analyzed during the Obama presidency, they referenced President Obama 53 out of 121 days (43.80\%), and he was referenced an average of 0.49 times per day. In the Trump presidency, however, the ACLU drastically changed both how often they referenced the president and how frequently they would do so per day. In the Trump presidency, they referenced President Trump 89 out of 98 days (90.82\%), and he was referenced an average of 3.41 times per day. See Tables 1 and 2 and Figure 1 on the next pages for more details. 


\begin{tabular}{|l|l|l|l|}
\hline & Bush & Obama & Trump \\
\hline Election Years & $5 / 9$ days $(55.56 \%)$ & $14 / 28$ days $(50.00 \%)$ & $4 / 13$ days (30.77\%) \\
\hline Inauguration Years & $3 / 21$ days $(14.29 \%)$ & $16 / 18$ days $(88.89 \%)$ & $19 / 19$ days (100\%) \\
\hline Civil Liberties Cases & $6 / 11$ days $(54.55 \%)$ & $16 / 62$ days $(25.81 \%)$ & $72 / 72$ days $(100 \%)$ \\
\hline $\begin{array}{l}\text { Next President's Election } \\
\text { Year }\end{array}$ & $9 / 11$ days $(81.82 \%)$ & $7 / 13$ days $(53.85 \%)$ & - \\
\hline \begin{tabular}{l} 
Total \\
\hline
\end{tabular} & $\mathbf{2 3 / 5 2}$ days $(\mathbf{4 4 . 2 3 \% )}$ & $\mathbf{5 3 / 1 2 1}$ days $(\mathbf{4 3 . 8 0 \% )}$ & $\mathbf{8 9 / 9 8}(\mathbf{9 0 . 8 2 \% )}$ \\
\hline
\end{tabular}

Table 1: Percentage of days the president is mentioned at least once (Note: there were six days of overlap between the inauguration year and civil liberties cases in the Trump era)

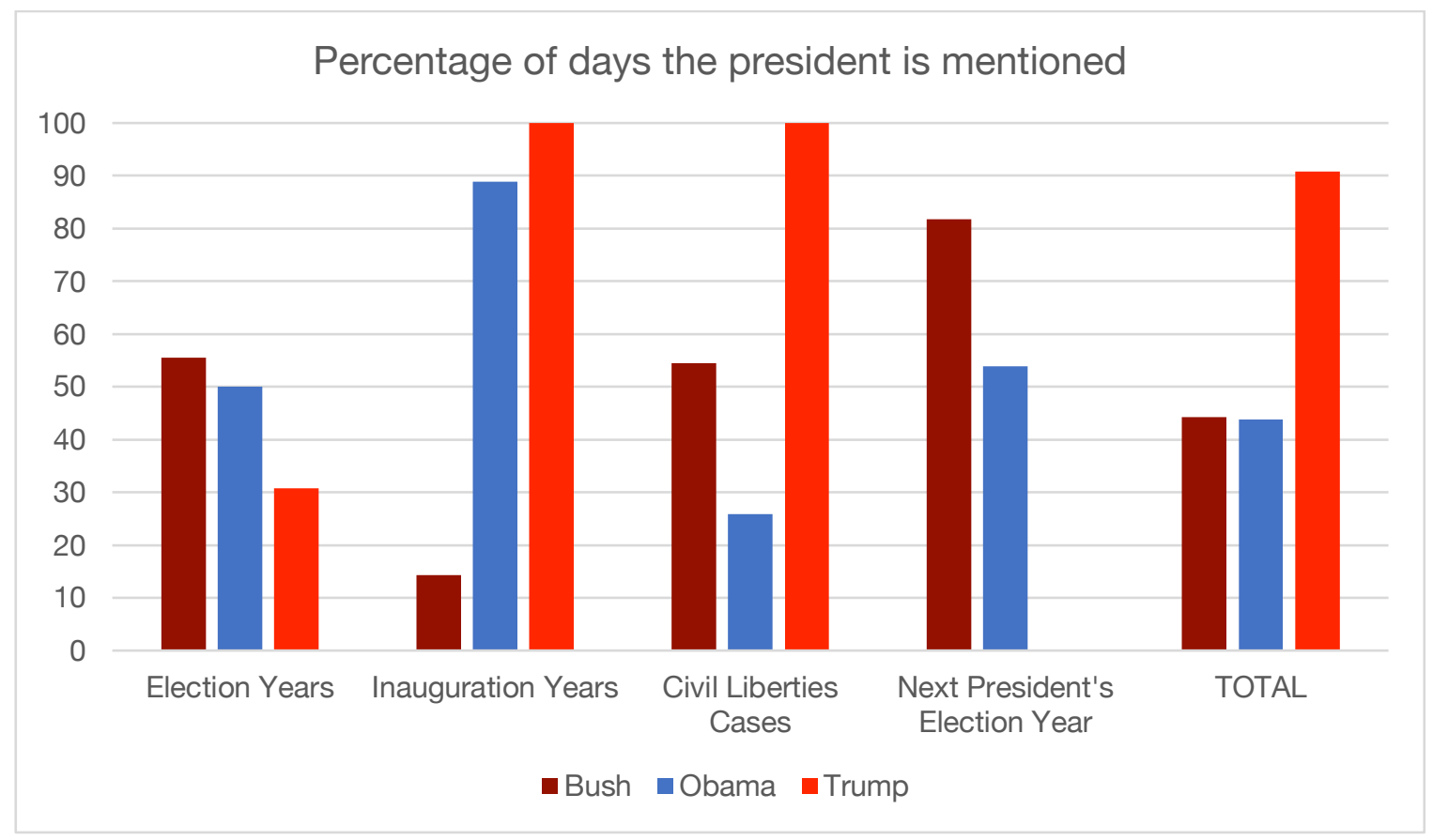

Figure 1: Number of days the president is mentioned at least once *Note: President Trump has only been president for one term; therefore, there is no data for the Next President's Term 


\begin{tabular}{|l|l|l|l|}
\hline & Bush & Obama & Trump \\
\hline Election Years & 0.56 times/day & 0.68 times/day & 0.84 times/day \\
\hline Inauguration Years & 0.14 times/day & 1.22 times/day & 4.67 times/day \\
\hline Civil Liberties Cases & 1 time/day & 0.34 times/day & 3.67 times/day \\
\hline $\begin{array}{l}\text { Next President's Election } \\
\text { Year }\end{array}$ & 1.18 times/day & 0.69 times/day & - \\
\hline $\begin{array}{l}\text { Rate for All Days } \\
\text { Analyzed }\end{array}$ & $\mathbf{0 . 4 4}$ times/day & $\mathbf{0 . 4 9}$ times/day & $\mathbf{3 . 4 1}$ times/day \\
\hline
\end{tabular}

Table 2: Average number of times the president is mentioned in a day

Similarly, the ACLU drastically increased both how often they referenced President Trump in a negative way and how many negative references there were in a day. For the documents analyzed during the Bush presidency, the ACLU negatively referenced President Bush 15 out of 52 days (28.85\%), and he was referenced negatively an average of 0.37 times per day. For the documents analyzed during the Obama presidency, the ACLU negatively referenced President Obama 14 out of 121 days (11.57\%), and he was referenced negatively an average of 0.13 times per day. For the documents analyzed during the Trump presidency, the ACLU negatively referenced President Trump 87 out of 98 days (88.78\%), and he was referenced negatively an average of 3.23 times per day. See Tables 3 and 4 and Figure 2 below for more details.

\begin{tabular}{|l|l|l|l|}
\hline & Bush & Obama & Trump \\
\hline Election Years & $3 / 9$ days $(33.33 \%)$ & $3 / 28$ days $(10.71 \%)$ & $4 / 13$ days $(30.77 \%)$ \\
\hline Inauguration Years & $2 / 21$ days $(9.52 \%)$ & $0 / 18$ days $(0.00 \%)$ & $19 / 19$ days $(100 \%)$ \\
\hline Civil Liberties Cases & $6 / 11$ days $(54.55 \%)$ & $11 / 62$ days $(17.74 \%)$ & $70 / 72$ days $(97.22 \%)$ \\
\hline $\begin{array}{l}\text { Next President's Election } \\
\text { Year }\end{array}$ & $4 / 11$ days $(36.36 \%)$ & $0 / 13$ days $(0.00 \%)$ & - \\
\hline Total & $\mathbf{1 5 / 5 2}$ days $(\mathbf{2 8 . 8 5 \% )}$ & $\mathbf{1 4 / 1 2 1}$ days $(\mathbf{1 1 . 5 7 \% )})$ & $\mathbf{8 7 / 9 8}$ days $(\mathbf{8 8 . 7 8 \%})$ \\
\hline
\end{tabular}


Table 3: Percentage of days the president is mentioned negatively at least once (Note: there were six days of overlap between the inauguration year and civil liberties cases in the Trump era)

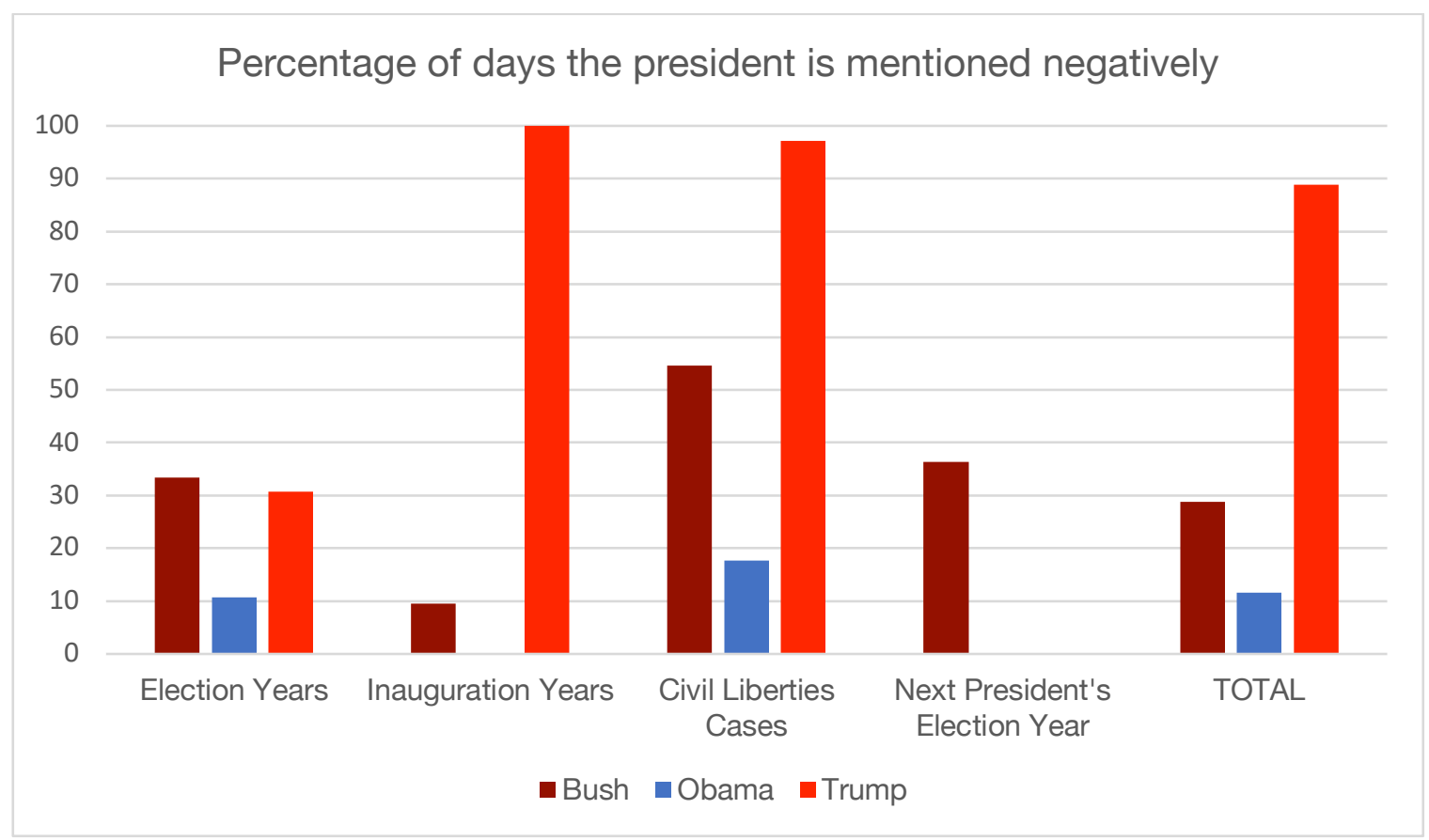

Figure 2: Number of days the president is mentioned negatively at least once (*Note: President Obama was mentioned negatively zero times during his inauguration years and during the next president's election year;

President Trump is still in his first term, so no data is available for the next president's election year)

\begin{tabular}{|c|c|c|c|}
\hline & Bush & Obama & Trump \\
\hline Election Years & 0.33 times/day & 0.11 times/day & 0.69 times/day \\
\hline Inauguration Years & 0.10 times/day & 0.00 times/day & 4.44 times/day \\
\hline $\begin{array}{c}\text { Civil Liberties Cases } \\
\text { Next President's Election } \\
\text { Year }\end{array}$ & 0.91 times/day & 0.21 times/day & 3.49 times/day \\
\hline $\begin{array}{c}\text { Rate for All Days } \\
\text { Analyzed }\end{array}$ & 0.64 times/day & 0.00 times/day & - \\
\hline \begin{tabular}{c} 
0.37 times/day \\
\hline
\end{tabular} & $\mathbf{. 1 3}$ times/day & $\mathbf{3 . 2 3}$ times/day \\
\hline
\end{tabular}

Table 4: Average number of times the president is mentioned negatively in a day

In addition to the sharp increase in the number of days the ACLU spoke negatively about President Trump, their critiques also covered a wider variety of civil liberties issues than with Presidents Bush and Obama. Of all instances of negative rhetoric or imagery against President 
Bush, nine civil liberties codes were referenced; for President Obama, four civil liberties codes were referenced negatively; for President Trump, 16 civil liberties codes were referenced negatively. Table 5 outlines these civil liberties codes and the number of times the president was negatively mentioned in reference to them. Appendix E further details this information by timeframe. These civil liberties examples are even more stark when considering the presidential timelines: Presidents Bush and Obama were in office for eight years; President Trump has only been in office for four.

\begin{tabular}{|c|c|c|c|}
\hline & $\begin{array}{c}\text { \# of times against } \\
\text { Bush }\end{array}$ & $\begin{array}{l}\text { \# of times against } \\
\text { Obama }\end{array}$ & $\begin{array}{c}\text { \# of times against } \\
\text { Trump }\end{array}$ \\
\hline $1 \quad$ Abortion & 1 & 0 & 3 \\
\hline 2 Children's rights & 0 & 0 & 0 \\
\hline $\begin{array}{rr}3 & \begin{array}{r}\text { Death penalty/capital } \\
\text { punishment }\end{array} \\
\end{array}$ & 0 & 0 & 0 \\
\hline $4 \quad$ Euthanasia & 0 & 0 & 0 \\
\hline $5 \quad$ Free Speech & 2 & 0 & 3 \\
\hline 6 Government surveillance & 3 & 0 & 19 \\
\hline $7 \quad$ Gun rights & 0 & 0 & 0 \\
\hline 8 Healthcare & 2 & 0 & 15 \\
\hline $\begin{array}{lll}9 & \text { Immigration }\end{array}$ & 0 & 7 & 51 \\
\hline $\begin{array}{r}10 \text { Incarceration and/or police } \\
\text { issues }\end{array}$ & 3 & 3 & 13 \\
\hline 11 Military & 0 & 0 & 12 \\
\hline 12 Native American rights & 0 & 0 & 0 \\
\hline 13 Press & 0 & 0 & 0 \\
\hline 14 Privacy & 4 & 0 & 3 \\
\hline 15 Property rights & 0 & 0 & 0 \\
\hline 16 Race relations & 0 & 0 & 5 \\
\hline $\begin{array}{ll}17 & \text { Religion }\end{array}$ & 2 & 0 & 36 \\
\hline 18 Right to assemble/protesting & 0 & 0 & 0 \\
\hline 19 Right to due process & 0 & 0 & 0 \\
\hline $\begin{array}{rr}20 \text { Right to marry/LGBTQ } \\
\text { rights }\end{array}$ & 0 & 0 & 17 \\
\hline $\begin{array}{rr}21 \text { Right to vote/voter } \\
\text { suppression }\end{array}$ & 0 & 0 & 16 \\
\hline 22 Terrorism & 0 & 0 & 0 \\
\hline 23 Torture & 6 & 4 & 10 \\
\hline 24 Transgender rights & 0 & 0 & 7 \\
\hline
\end{tabular}




\begin{tabular}{|r|c|c|c|}
\hline $25 \begin{array}{r}\text { Women's rights, gender } \\
\text { rights or feminism }\end{array}$ & 0 & 0 & 10 \\
\hline $\mathbf{2 6}$ Other (please specify) & 9 & 3 & 60 \\
\hline
\end{tabular}

Table 5: Number of times the president was negatively mentioned on the ACLU homepage in reference to a given civil liberties issue (Note: the number of documents analyzed varied by president; see Appendix E for a detailed breakdown)

As outlined in Appendix E, the majority of criticism toward President Bush happened during the $A C L U v$ v. NSA lawsuit. During this timeframe, the ACLU negatively referenced President Bush in regard to the following civil liberties topics: free speech, government surveillance, incarceration and/or police issues, privacy and religion, with government surveillance and privacy being the two main topics $(27.27 \%$ and $36.36 \%$ of documents analyzed, respectively). These two topics were the main civil liberties issues in $A C L U v$. NSA, thus showing that it was their priority against Bush. During the Obama administration, the ACLU only mentioned President Obama in a negative way during the R.I.L.-R. v. Johnson case, with a focus on immigration $(9.68 \%)$, which was the main civil liberties issue in the case. It is important to note that based on the documents analyzed, the ACLU criticized President Bush more heavily for his civil rights infringement than President Obama's, with nearly triple the percentage of negative mentions. This shows a bias in favor of the democratic president.

President Trump was unique in that his harshest critiques were not just during the lawsuit timeframe like the previous presidents; the ACLU was also heavily critical of him during his inaugural period, although there was some overlap between this timeframe and Darweesh $v$. Trump. The percentage of times they brought up civil liberties issues drastically increased from the Bush and Obama presidencies. For example, during Trump's inaugural period, the ACLU referenced him negatively in regard to immigration $100 \%$ of the time, religion $63.16 \%$ of the time, right to marry/LGBTQ+ rights $47.37 \%$ of the time, torture $31.58 \%$ of the time and 
women's rights/gender rights/feminism $31.58 \%$ of the time, with immigration and religion being the two main civil liberties issues in Darweesh v. Trump. During the lawsuit, the ACLU actually reduced the percentage of times they mentioned him negatively in regard to immigration and religion (51.39\% and $37.50 \%$, respectively); however, they still focused on these issues significantly more than they did Bush's (government surveillance $27.27 \%$; privacy $36.36 \%$ ) and Obama's (immigration 9.68\%) civil liberties infringements.

Negative imagery was another interesting aspect of this study. During President Bush's terms, there was only one negative image of him in the documents analyzed. During President Obama's terms, there were no negative photos of him, but there were two negative photos of President Bush. During the Trump presidency, there were 29 negative images of him (3 during the election year, 8 during the inauguration year and 18 during Darweesh v. Trump).

It is important to note that the Internet has vastly changed since the early 2000 s, and web pages now contain more images, links and videos, and thus more opportunities for negative imagery. Due to this, one cannot conclude that the ACLU has become more partisan in the Trump era with regard to negative imagery because they have drastically increased the amount of imagery present on their homepages in general. One can, however, analyze the images used and the magnitude of partisanship within them. Some notable examples of negative imagery on highlighted on the next page. 

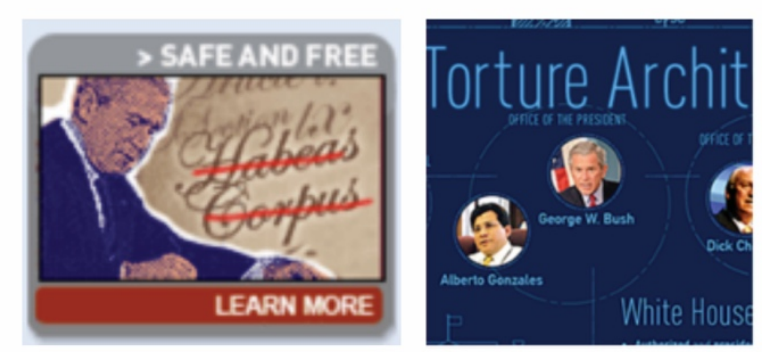

Growing Chorus Demands
Criminal Investigation into
Torture Program

12/22/2014 - Calls for a criminal investigation into the Bush-era torture program described in the Senate report released earlier this month are beginning to mount.

Read More s
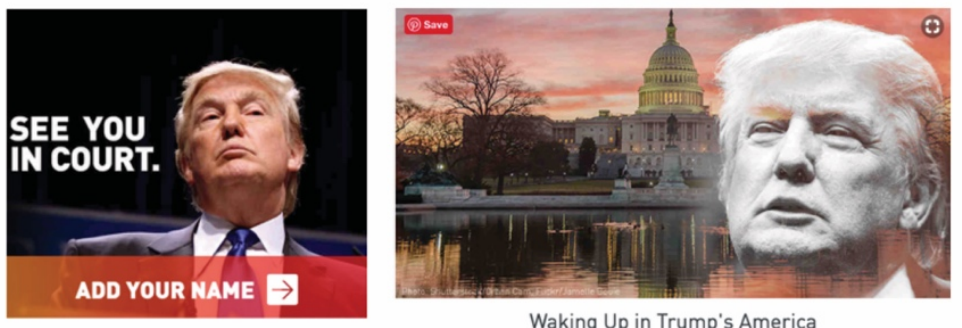

Waking Up in Trump's America

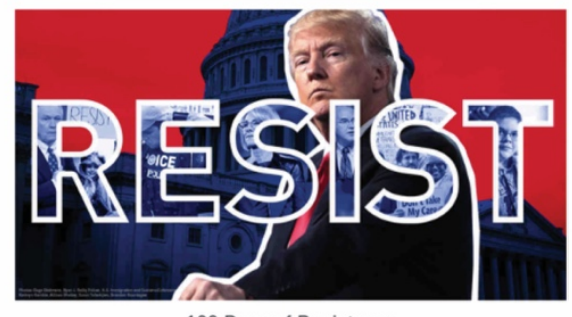

100 Days of Resistance

Figure 3: Examples of negative images of President Bush from March 23, 2007 and Dec. 23, 2014; examples of negative images of President Trump from Nov. 10, 2016, Jan. 23, 2017 and April 30, 2017 (none of the images of President Obama analyzed were deemed negative)

Figure 3 shows a few examples of negative imagery toward Presidents Bush and Trump; there were no images deemed negative of President Obama. Whereas the negative images of President Bush accompany a specific issue (i.e., habeas corpus and torture), the negative images of President Trump are more general. The "See You in Court" graphic specifically frequented the ACLU's homepage.

Additionally, the ACLU had some unique art choices depicting President Trump (see Figure 4 on the next page). This art style is reminiscent of Soviet-era Constructivist posters, with sharp angles and a blocky silhouette (see Bowdoin College Museum of Art (n.d.) for examples of this style). This art choice is relevant because of how important Russia was at the time in U.S. politics; Russia had just interfered in the 2016 presidential election, attempting to help elect Donald Trump and cause division in the U.S. by hacking into Trump's opponent, Hillary Clinton's, campaign computers to find and leak damning information, creating fake social media accounts targeting Americans with the goal of "sowing discord in the U.S. political system" (p. 
14), purchasing advertisements against Clinton on social media, and more (Mueller, 2019). This is an interesting, subtle way of the ACLU tying President Trump to the Russian scandal. The ACLU used this graphic depiction of the president multiple times throughout the dates analyzed.

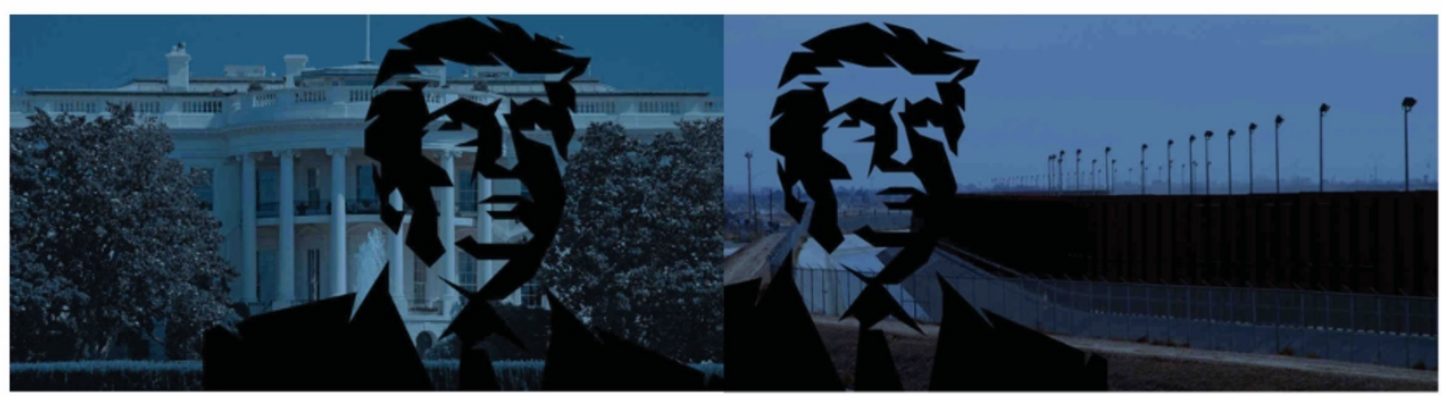

Donald Trump: A One-Man Constitutional Crisis Trump Begins Unconstitutional Program of Anti-Muslim $11 / 11 / 16$ Discrimination $1 / 30 / 17$

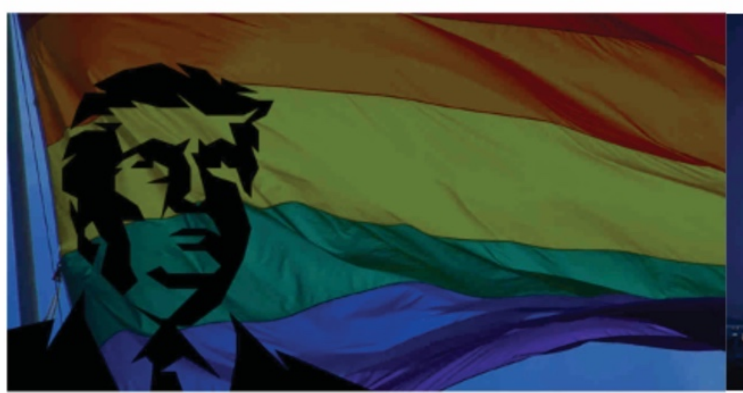

Discrimination Disguised As Religious Freedom Is Still Discrimination $2 / 5 / 17$

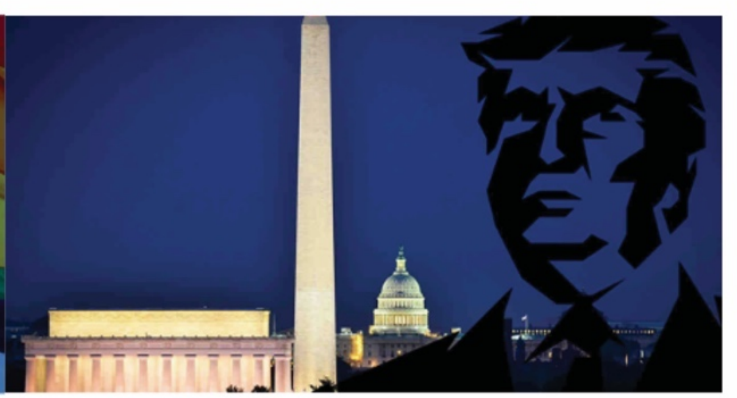

Why the ACLU Has Called for an Investigation but Not Impeachment Now

Figure 4: Drawings of President Trump in an art style reminiscent of Soviet-era Constructivist posters

Based on the documents analyzed, some interesting patterns emerged. First, the ACLU did not reference any new presidential candidate before Election Day on their homepage. The most stark example of this was with President Trump; he was not mentioned at all prior to Election Day 2016, but after he won the election, he was mentioned in every document following (98 days). There were only two days out of the 98 analyzed where he was not referenced in a negative way at least once on their homepage. The fact that they did not discuss candidates prior to the election on their homepage demonstrates the ACLU's mission of a nonpartisan organization. They are showing that they do not want to influence the election; rather, their goal 
is to hold whomever is in the presidency to the Constitution. On the other hand, in the case of the 2016 election, it is likely that they did not believe Trump would win the election. Polls overwhelmingly showed Hillary Clinton winning (RealClear Politics, n.d.), and ACLU Executive Director Anthony D. Romero and Director of the ACLU Affiliate Support \& Nationwide Initiative Geri E. Rozanski even admitted the following after Election Day (Romero, 2017):

While we cannot claim to have predicted — or frankly even imagined —a Trump presidency, we came on board more than 15 years ago knowing that the ACLU needed a plan for smart and strategic growth in order to confront the inevitable civil liberties crises ahead (p. 25).

Second, another theme that emerged was that while the ACLU was typically critical of individual unconstitutional actions, they were sometimes critical of the president as a person when referring to Presidents Bush and Trump. See Figure 5 below for detailed examples. Particularly with President Trump, the ACLU has argued that he is a general threat to the Constitution and that they will be holding him accountable. 


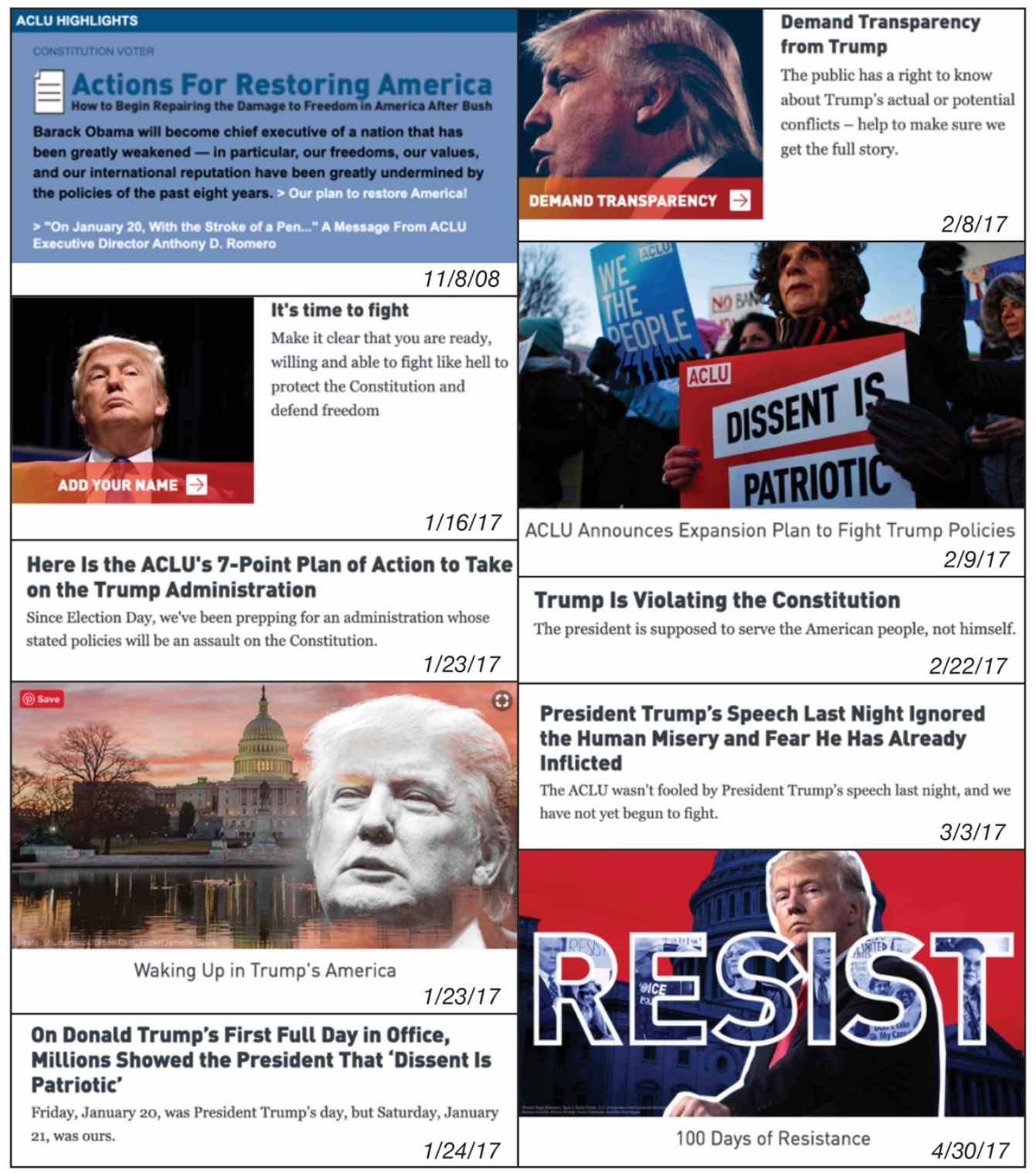

Figure 5: Examples of the ACLU attacking the president as a person rather than individual unconstitutional actions

Third, in a stark contrast to the ACLU's condemning of the president as a person, the

ACLU often used more gentle language when speaking about President Obama, oftentimes

suggesting policy changes and including terms like should. See Figure 6 below for detailed

examples. While they were not always so gentle with their language toward President Obama

(for example, on June 19, 2015, they featured an article on their homepage stating, "In Violation 
of the Constitution, Obama is Deporting Asylum-Seekers Without Oversight from the Courts") this is something that stood out of the data that was not present for Presidents Bush and Trump. Additionally, the ACLU also praised President Obama on multiple occasions. See Figure 7 for examples.

\section{Asks for President Obama and the White House "}

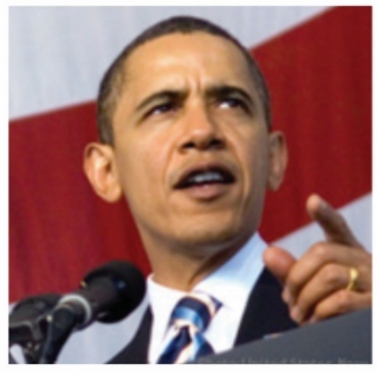

10 Goals for President Obama \& The White House

The Obama administration can achieve the following ten things in the first 100 days of the new term and earn the label of the 'civil liberties presidency.'

Learn More s

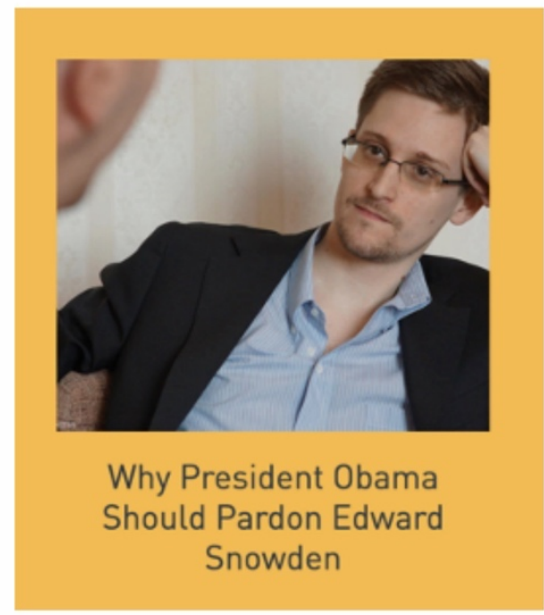

4/8/2013 | PRESS RELEASE | EMPLOYMENT

ACLU Asks President Obama to Take Executive Action On Equal Pay $»$

The Most Important Step President Obama Can Take to Stop the Use of Religion to Discriminate Bush-era hangover memos continue to allow taxpayer-funded discrimination.

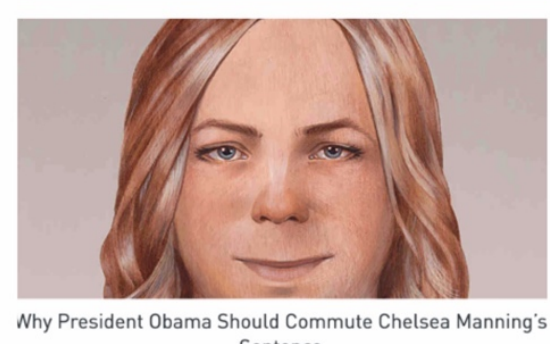

Sentence

Figure 6: Examples of the ACLU using a more gentle language with President Obama from Feb. 3, 2013 (3 Asks and 10 Goals), April 8, 2013, Aug. 24, 2015, Oct. 10, 2016 and Jan. 16, 2017 
ACLU Commends Obama-Biden Ban on Discrimination Against LGBT Applicants for Jobs in the New Administration

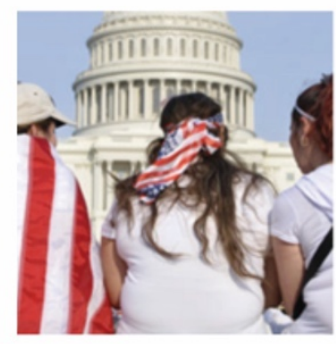

As a Criminal Justice Reform Advocate, Obama's Farewell Speech Felt Like a Full Circle Moment One of the defining themes of President Obama's legacy was his constant push for criminal justice reform.
ACLU Commends Obama on New Policy Directive Protecting National Security Whistleblowers

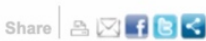

Thanks to President Obama, My American Dream Won't Become a Nightmare

02/11/2015 - This is my family's American Dream story. I am a divorced, single mother, and an undocumented immigrant. I have resided in the United States for almost 30 years. We came from Pakistan,

\section{Read More :}

\section{As Obama's Presidency Comes to an End, Take Some Time to Reflect but Never Forget to Keep Climbing \\ On Martin Luther King Day, the director of the ACLU's racial justice program reflects on Obama's legacy.}

Figure 7: Examples of the ACLU using positive language with President Obama from Nov. 8, 2008, Oct. 13, 2012, Feb. 18, 2015 and Jan. 16, 2017 (last two images)

The fourth thing that emerged from the data was that the ACLU updated their homepage more frequently in the Trump era. While it is natural that they would have had the resources available to update more frequently compared to the earlier presidencies, the homepage was often inundated with articles, images and references to President Trump and his administration. It was not infrequent to have six or more references to the president in any given day, and the maximum number of references was up to nine (January 24, 2017). The increase in updates could be attributed to the amount of civil liberties the president was violating, or it could also be attributed to the newfound funding from donors (e.g., Stack, 2017).

There was not necessarily a pattern of the ACLU standing up for President Trump, but there were two important examples of this that need to be highlighted. First, on April 23, 2017 , the ACLU featured an article on their homepage titled, Donald Trump Has Free Speech Rights, Too (Figure 8), where they argued that what he was being sued for at the time was not actually unconstitutional. How they justified their position in the article was interesting and reminiscent of their work as a nonpartisan nonprofit: "Few organizations have been more engaged in fighting 
President Donald Trump's attacks on civil liberties and civil rights than the ACLU. But it's important to remember that political candidates — including Donald Trump — have constitutional rights, too" (Rowland, 2017).

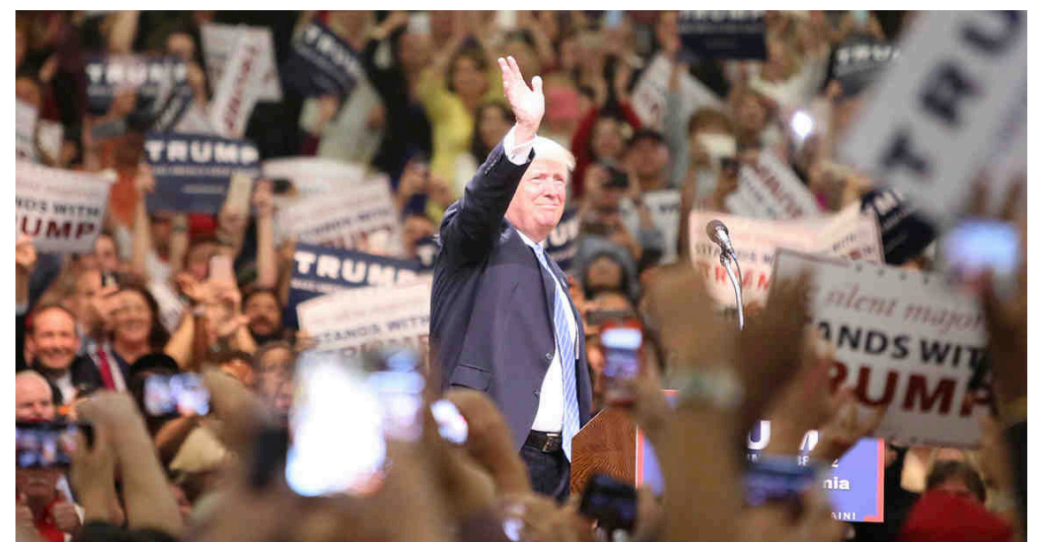

Donald Trump Has Free Speech Rights, Too

Figure 8: ACLU Article highlighted on their April 9, 2017 homepage

Second, on May 4, 2017, the ACLU posted the following headline urging followers to not rush to calling for impeachment of the president: "Why the ACLU has Called for an Investigation but Not Impeachment Now: The rule of law demands we not rush to judgment. President Trump can only be impeached if the facts support it."

In summary, there were some subtle changes in how the ACLU talked about the president between the Bush and Obama administrations and a drastic change from Obama to Trump. Both Presidents Bush and Obama were referenced a similar amount of times on the ACLU homepage ( $44.23 \%$ and $43.80 \%$ of the time, respectively) and they were referenced at a similar frequency per day (0.44 and 0.49 times per day, respectively). President Bush was negatively referenced about 2.5 times more frequently than President Obama (28.85\% versus $11.57 \%$ of the time). This does not prove that the ACLU was biased toward President Obama as Bush also had a wider 
variety of civil liberties infringements than Obama (9 civil liberties topics versus 4$)$, and the Democratic platform often aligns more with the ACLU's mission.

That said, there was a clear bias in how the ACLU reported on civil liberties issues when actively suing the U.S. government. The two main civil liberties issues in the lawsuit against the Bush administration were government surveillance and privacy. The ACLU spoke negatively about President Bush in regard to these two civil liberties $27.27 \%$ and $36.36 \%$ of the time respectively. Conversely, when the ACLU was in a lawsuit against the Obama administration, they only spoke negatively about President Obama in regard to immigration (the main civil liberties infringement in the lawsuit) $9.68 \%$ of the time. This shows that while the ACLU has repeatedly brought up that they are nonpartisan and hold Democrats to this high standard, too (see Rowland, 2017), they are not as nonpartisan as they claim to be.

While the changes between the Bush and Obama administrations were subtle and one would have to look into the data to see any bias, the changes between the Obama and Trump administrations were stark. Whereas Presidents Bush and Obama were mentioned fewer than half of the days analyzed, President Trump was mentioned $90.82 \%$ of the time, and whereas Presidents Bush and Obama were mentioned on average once every other day, President Trump was referenced on average 3.41 times per day. While there was a difference in how often they negatively referenced Bush compared to Obama (28.85\% versus $11.57 \%$ ), they negatively referenced President Trump $88.78 \%$ of the time with an average of 3.49 negative references per day. The ACLU's criticisms of Trump were varied, too, with 16 civil liberties codes being negatively referenced with him. This alludes to their "One-Man Constitutional Crisis" statement. 
The answer to RQ1 ("How has the ACLU changed its partisan rhetoric toward political figures over the years, if at all?") is drastically. The next part of this study will analyze what that means and the ethics behind it.

\section{RQ2 METHODOLOGY}

Since the content analysis showed that the ACLU has indeed both increased their amount of partisan rhetoric and the magnitude of that partisan rhetoric in the Trump era, this study then sought to analyze the ethical impacts of this change and answer Research Question 2 (a) Is it ethical for a nonpartisan nonprofit organization to use partisan language against an individual rather than his or her policies and executive orders? (b) How does partisanship affect the various ACLU stakeholders? To do so, an ethical analysis was conducted to compare the organization's rhetoric against the ACLU mission statement (ACLU, n.d.) and The Independent Sector's Statement of Values and Code of Ethics for Nonprofit and Philanthropic Organizations (Independent Sector, 2004). The ACLU Mission Statement is outlined in Appendix F, while the Code of Ethics is in Appendix G.

Codes of ethics can admittedly be problematic for judging the true ethicality of an organization. As Bowen (2007) notes, codes may vary by profession or country of origin, and sometimes their information is too vague or contradictory. It is also not necessarily true that the ACLU abides by the nonprofit code above; however, this is still a good framework for understanding what is typically defined as ethical in the nonprofit and philanthropic fields in the United States.

To combat this limitation, a discussion of Bowen, Hung-Baesecke and Chen's (2016) ethical expansion of the organization-public relationships theory is included. The authors posit that ethics is a precursor to the OPR model because of its strong ties with trust. Since the OPR 
model focuses on the importance of relationships, attention is given to the various stakeholders of the ACLU and how partisan rhetoric may affect them. These stakeholders include: the donors/ACLU's dues-paying members, those they represent in court, the American public at large (due to their mission's focus on Constitutionality) and, as an IRS-registered nonprofit organization, the U.S. government.

\section{RQ2 RESULTS}

First, this study compared the ACLU's rhetoric against their mission statement (ACLU, n.d.) (Appendix F). The ACLU Mission Statement outlines their history, why they stand up for civil liberties, why they have represented controversial groups in court and how they achieve their goals as a nonpartisan nonprofit organization. Their statement on why they represent controversial groups and people is particularly noteworthy:

The ACLU is frequently asked to explain its defense of certain people or groups particularly controversial and unpopular entities such as the Ku Klux Klan, the Nation of Islam, and the National Socialist Party of America. We do not defend them because we agree with them. Rather we defend their right to free expression and free assembly.

Historically, the people whose opinions are the most controversial or extreme are the people whose rights are most often threatened. Once the government has the power to violate one person's rights, it can use that power against everyone. We work to stop the erosion of civil liberties before it's too late. (ACLU, n.d.)

This is something that the organization is clearly proud of; they hold civil liberties in such high regard that they are even willing to represent groups they disagree with to defend their rights. This is also something that shows that they are truly nonpartisan, even beyond a left- and right-wing definition.

The organization has drastically changed in the Trump era, though. They have focused less on representing and supporting controversial groups and more on fighting the current White House administration both in court and in their communications. This does not mean, however, 
that they have changed their mission or their nonpartisan values. It means that the United States is in such a unique, unprecedented position that ethically they have to take on the administration wholeheartedly. The Trump presidency, with its attacks on the civil liberties of Muslims, Black individuals, immigrants, Native peoples, protestors, the LGBTQ+ community, those living in poverty, prisoners, members of the U.S. military, women and indeed U.S. citizens as a whole, is itself an attack on the ACLU's mission. It could be considered unethical for the organization to not take this stance in the name of neutrality.

Next, this study compared the ACLU's rhetoric against The Independent Sector's Statement of Values and Code of Ethics for Nonprofit and Philanthropic Organizations (Appendix G). While this document largely focuses on best practices for nonprofits (such as responsibilities for governing boards and fundraising), it also highlights the important values of the sector, including:

"Commitment to the public good; Accountability to the public; Commitment beyond the law; Respect for the worth and dignity of individuals; Inclusiveness and social justice; Respect for pluralism and diversity; Transparency, integrity and honesty; Responsible stewardship of resources; and Commitment to excellence and to maintaining the public trust" (p. 1)

Some of these values are particularly important for this study, namely commitment to the public good, inclusiveness and social justice and maintaining the public trust. This requires a difficult balance from the ACLU as these three tenets can be at odds with each other: commitment to the public good focuses on doing what is best for the majority of people while inclusiveness and social justice implies doing what is best for those skipped over in society. Maintaining the public trust is an even more difficult value as the public as a group is multidimensional, emotional and does not necessarily respond to logical claims. Even if the ACLU is justified in their actions, their partisan rhetoric could make them be seen as just another 
left-wing advocacy group, thus losing public trust. This value is particularly important as it ties into the importance of trust in POPR theory (Bowen, Hung-Baesecke \& Chen, 2016).

While analysis of these documents explains the justification for why the ACLU has been participating in an aggressive campaign against the president and his administration, this study sought to understand how this decision affects their various stakeholders. It's important to note that it does not affect all of them in the same way. The following stakeholders were analyzed: the donors/dues-paying members, those they represent in court, the American public and the U.S. government.

\section{Donors and ACLU's dues-paying members}

While there is likely a large overlap in donors and dues-paying members, those who are only donors are unique in that they are not actually affiliated with the organization but expect certain outcomes from them. This group of stakeholders is important for any nonprofit, but they have played a special role with the ACLU in the Trump presidency due to the unprecedented increase in donations following Trump's election and his announcement of the executive order barring people from select Middle Eastern countries from entering the U.S.

These newfound donors do not necessarily have a stake in the ACLU as an organization; it is possible that they do not care that the ACLU is nonpartisan, that they have represented a variety of controversial organizations in court or that as an official, registered nonprofit they have administrative needs and governing rules to follow. They likely only care that the ACLU is fighting for issues that they deem important.

As noted in the Independent Sector's code of ethics (Independent Sector, 2004), donors have certain rights that nonprofits should work to maintain, including assuring "their gifts will be used for the purposes for which they were given" (p. 3). When the ACLU received these 
donations, they had an obligation to the donors. Many Americans are choosing to voice their concerns monetarily through donations, and the ACLU has a moral obligation to support them. Similarly, dues-paying members are financially supporting the organization; however, they hold more of a stake with the nonprofit.

Those they represent in court

As discussed earlier, the ACLU has represented a wide variety of people and groups in court. A hyper-partisan campaign against the president is not necessarily what is best for those they represent. If the ACLU is seen as an extremist left-wing organization, they may not be taken as seriously as other political nonprofits. While many of the more controversial nonprofits are fighting for one cause (e.g., PETA for animal rights, National Organization for Marriage for the opposition of same-sex marriage, etc.), the ACLU fights for a variety of civil liberties issues; if they get tied to one thing-attacking the Trump presidency-or tied to the Democratic party, they could very likely be pegged not credible, thus hurting those they represent in court. For this group of stakeholders, their partisan rhetoric could be seen as unethical.

\section{The American public}

The ACLU is unique in that they represent the American public at large due to their stance on protecting the Constitution and civil liberties. Whereas many nonprofits are only accountable to their donors, members and supporters, the ACLU is also accountable to the U.S as a whole, even those whom disagree with the organization.

In this way, the ACLU's steadfast approach to their mission is beneficial; they do not pick and choose cases or topics based solely on individuals they like and agree with-they focus only on if something is Constitutional or unconstitutional. An important example of this is when the ACLU posted articles reminding their supporters that President Donald Trump's civil 
liberties are still important while actively pursuing a critical campaign against him (i.e., Donald Trump Has Free Speech Rights, Too (Rowland, 2017) and Why the ACLU has Called for an Investigation but Not Impeachment Now (Cole, 2017).

\section{The U.S. government}

As a registered nonprofit with the IRS, the ACLU has certain rules and guidelines they have to follow to maintain this status. The ACLU holds a unique relationship with the government; on the one hand, they are accountable to it by having to follow these rules and guidelines, but on the other hand, they hold the government accountable by their mission statement. As is highlighted in OPR theory, trust is one of the most important factors in relationships, and this is a difficult balance that the ACLU (and other political nonprofits) have to maintain. How the ACLU handles things now can affect their relationships down the line with conservatives, especially if Trump wins reelection.

President Trump is an outlier with regard to how the ACLU has used partisan language, but there is even a distinct difference between how they spoke about the Bush and Obama administrations and how they specifically treated their civil liberties infringements. The ACLU spoke negatively about President Bush nearly triple the percentage of times they spoke negatively about President Obama. When comparing civil liberties cases against the presidential administrations, the ACLU referred to the case against President Bush negatively nearly a third more frequently than the case against President Obama. Additionally, the ACLU has often been complimentary and supportive of the Obama presidency. This shows that the ACLU has historically not been as welcoming to Republican administrations, and this hurts their relationship with the government as a whole as there are many types of people working in the public sector. 


\section{Limitations and Future Research}

There were a few limitations to this study that need to be noted. First, the Wayback Machine software is limited in daily "snapshots" the further back one goes. While there was an abundance of information on the Trump presidency, even multiple snapshots on a given day, there was a lack of information on the Bush presidency, particularly during his first term. Due to this lack of information, this study typically used percentages of the data available to compare presidencies quantitatively. Qualitatively, however, there were likely days that had noteworthy quotes and examples that were not available to be analyzed. It is also important to note that the Internet has changed vastly over the past two decades. Changes in rhetoric and the amount of times the ACLU was critical of the presidency could have changed more due to this change in technology rather than a change of the organization.

Second, the three presidencies compared were not the same length of time. Presidents Bush and Obama were both two-term presidents. President Trump, on the other hand, is a oneterm president. The data available for Presidents Bush and Obama spanned over their eight-year terms, while the data for this study on President Trump all took place within his first year in office. This is noteworthy, however, because of how frequently the ACLU was critical of President Trump. For example, of all instances of negative rhetoric or imagery against President Bush, nine civil liberties codes were referenced over eight years; for President Obama, four civil liberties codes were referenced negatively over eight years; for President Trump, 16 civil liberties codes were referenced negatively within his first year.

Third, while this study gained insight on the views of the ACLU from op-eds and articles from their executive director, interviews with members of the ACLU and its affiliates would have provided a richer understanding of how the ACLU has changed their rhetoric and why. 
Interviews could explore topics such as individuals' views on President Donald Trump, the ACLU's ethical responsibilities to their stakeholders and their views of the organization's nonpartisan mission.

Fourth, while this study included some analysis of visuals such as photographs and drawings, they were analyzed holistically along with the text. Other researchers (such as Shahira Fahmy) go more in depth on visual communications theory. Future researchers could examine the ACLU's communications through the theoretical lenses put forth in propaganda and visual communication literature.

This study focused solely on the American Civil Liberties Union; however, future research is needed on how other nonpartisan nonprofits have handled the Trump presidency. The ACLU is not the only nonprofit focused on civil liberties either; Great Nonprofits (n.d.) lists more than 600 small and large nonprofits and/or charities focused on a variety of civil liberties issues, ranging from gun rights to abolishing the death penalty. Future research could include analyses of these organizations to see if partisanship against the Trump presidency has become a trend or if there is a pattern among the types of civil liberties groups represented.

It's important to highlight that Donald Trump is the first president to regularly communicate to the people directly through social media rather than going through a public relations staff member or the press (resulting in the media having less of a gatekeeping role). His supporters often claim that he tells it like it is-(perhaps not like it is in reality but rather not through the filter of polished staff members). He often personally used Twitter around the clock to share unvetted information, resulting in sensationalist headlines that organizations like the ACLU may have felt warranted a response. Future research could delve into this presidential 
communication style to see if it affects the ACLU's rhetoric. Researchers may also find that the View from Nowhere theory may be applicable here, too.

Finally, the timing of this study and the ever-changing political landscape in 2020 made ending this study difficult. Former Vice President Joe Biden is projected to be president-elect; however, the Trump administration is still fighting state elections in court. Future research could focus on the effects of the Trump presidency on his own reelection campaign or how other campaigns will navigate their relationship with political nonprofits like the ACLU.

\section{DISCUSSION}

This study contributes to the larger understanding of the Trump presidency and how the ACLU, a nonpartisan nonprofit, has adapted to this cultural shift. This study sought to better understand how the ACLU has changed their rhetoric during the Trump presidency and to discuss the ethicality behind that decision to make a drastic change.

This study only delved into one small aspect of the Trump era: the effects on a nonpartisan, political nonprofit. Perhaps the change in their rhetoric should not be surprising given that organizations have become more political, more partisan and more critical of the presidency as a whole. Whereas private companies aligning themselves with politics was previously seen as bad for business, many do not have that choice today. Businesses like Nike, Netflix and Nordstrom have posted social media campaigns supporting the Black Lives Matter movement (Hsu, 2020), and 84 Lumber produced a controversial Super Bowl commercial about a Mexican family trying to start anew in the Unites States (O'Reilly, 2017). Now nine months into the Coronavirus epidemic, where more than 250,000 Americans have died (Johns Hopkins, 2020), many have blamed the United States' slow response and high number of deaths personally on President Trump. Our world feels different now. 
But while these organizations and companies feel forced to state their values on civil rights, they also risk upsetting those whom disagree or think that politically correct culture has gone too far. This study showed there is an opportunity for the ACLU to reach out to the conservative end of the spectrum and to better highlight their focus on Constitutionality rather than what is seen as liberal politics.

Perhaps the larger philosophical question is does politicization of nonpartisan groups (e.g., nonprofits, businesses, the media) benefit society or, as the Edelman Trust Barometer (2020) indicates, does it further divide our already polarized country? OPR theorists may predict the latter. 


\section{REFERENCES}

Abramson, A.J. \& Salamon, L.M. (2016). Prospects for nonprofits and philanthropy in the Trump presidency. Nonprofit Policy Forum, 7(4), 565-571.

$A C L U$ v. NSA, 493 F. 3d 644 (6 $6^{\text {th }}$ Cir. 2007).

American Civil Liberties Union. (n.d.). About the ACLU. Retrieved from https://www.aclu.org/about-aclu

American Civil Liberties Union. (n.d.). ACLU History. Retrieved from https://www.aclu.org/about/aclu-history

American Civil Liberties Union. (n.d.). ACLU v. NSA - Challenge to warrantless wiretapping. Retrieved from https://www.aclu.org/cases/aclu-v-nsa-challenge-warrantless-wiretapping

American Civil Liberties Union. (2018). ACLU annual report 2017. Retrieved from https://www.aclu.org/other/aclu-annual-report-2017

American Civil Liberties Union. (2019). ACLU annual report 2018. Retrieved from https://www.aclu.org/other/aclu-annual-report-2018

American Civil Liberties Union. (2020). ACLU annual report 2019. Retrieved from https://www.aclu.org/other/aclu-annual-report-2017

American Civil Liberties Union. (n.d.). Civil liberties and civil rights voters emerge as a key 2020 constituency. Retrieved from https://www.aclu.org/press-releases/aclu-supporterscontribute-482-million-political-giving-both-parties

American Civil Liberties Union. (n.d.). Court Battles. Retrieved from https://www.aclu.org/defending-our-rights/court-battles

American Civil Liberties Union. (2017). Home page. Retrieved from https://www.aclu.org/

American Civil Liberties Union. (2017). Muslim Ban Cases. Retrieved from https://www.aclu.org/files/muslim-ban/MuslimBanCases_2.9.17.pdf

American Civil Liberties Union. (n.d.). RILR v. Johnson. Retrieved from https://www.aclu.org/cases/rilr-v-johnson

American Civil Liberties Union Pennsylvania. (n.d.). ACLU vs. ACLU Foundation.

Bowdoin College Museum of Art. (n.d.). Constructing Revolution: Soviet Propaganda Posters from between the World Wars. Retrieved from https://www.bowdoin.edu/artmuseum/pdf/Bowdoin-Constructing-Revolution-checklist.pdf 
Bowen, S. (2007). Ethics and public relations. Institute for Public Relations. Retrieved from https://instituteforpr.org/ethics-and-public-relations/

Bowen, S.A., Hung-Baesecke, C.J.F., \& Chen, Y.R.R. (2016). Ethics as a precursor to organization-public relationships: Building trust before and during the OPR model. Cogent Social Sciences, 2(1), 1141467.

Canaparo, G. (2020). The ACLU loses its way. The Heritage Foundation. Retrieved from https://www.heritage.org/the-constitution/commentary/the-aclu-loses-its-way

Chandler, A. (2016). The post-election surge in donations. The Atlantic.

CNN (n.d.). Presidential results. Retrieved from https://www.cnn.com/election/2016/results/president

Cole, D. (2017). Why the ACLU has called for an investigation but not impeachment now. $A C L U$. Retrieved from https://www.aclu.org/blog/national-security/why-aclu-hascalled-investigation-not-impeachment-now

Conklin, M. (2019) Was the 'Trump Bump' a One-Time Phenomenon for Charities? 32 CHRON. PHILANTHROPY 50. Available at SSRN: https://ssrn.com/abstract=3608736

Cramer, R. (2017). EMILY's List expands after 16,000 women reach out about running for office. Buzzfeed News.

Darweesh v. Trump, U.S. Dist. LEXIS 13243 (E.D.N.Y., 2017)

Douglas, J. (1983). Why Charity? Beverly Hills: Sage.

Fei, R. \& Colvin, G. (n.d.). Happy Families: 501(c)(3)s with 501(c)(4) Affiliates - A Primer. Adler \& Colvin. Retrieved from https://calnonprofits.org/images/Convention/2015_Convention/2016ResourcesAttachments.pdf

Edelman Trust Barometer. (2020). Retrieved from https://www.edelman.com/sites/g/files/aatuss 191/files/202001/2020\%20Edelman\%20Trust\%20Barometer\%20Global\%20Report.pdf

EMILY's List. (n.d.). Our history. Retrieved from https://www.emilyslist.org/pages/entry/our-history

Freedman, P., \& Goldstein, K. (1999). Measuring Media Exposure and the Effects of Negative Campaign Ads. American Journal of Political Science, 43(4), 11891208. 
Gant, M. M., \& Luttbeg, N. R. (1987). The cognitive utility of partisanship. Western Political Quarterly, 40(3), 499-517.

Gantt Shafer, J. (2017). Donald Trump's “political incorrectness": Neoliberalism as frontstage racism on social media. Social Media + Society, 3(3).

Garber, M. (2016). John Oliver, activist. The Atlantic.

Gorovitz, E. (2017). Public health and politics: using the tax code to expand advocacy. The Journal of Law, Medicine \& Ethics, 45(1_suppl), 24-27.

Graham, D.A. (2016). Which Republicans Oppose Donald Trump? A Cheat Sheet. The Atlantic. Retrieved from https://www.theatlantic.com/politics/archive/2016/11/where-republicansstand-on-donald-trump-a-cheat-sheet/481449/

Great Nonprofits. (n.d.). Find civil liberties nonprofits and charities. Retrieved from https://greatnonprofits.org/categories/view/civil-liberties/page: 1

Greene, S. (2002). The social-psychological measurement of partisanship. Political Behavior, 24(3).

Hansmann H. (1987). Economic Theories of Nonprofit Organization. In W. W. Powell (Ed.), The Nonprofit Sector: A Research Handbook. New Haven: Yale University Press.

Harrison, V. S., Xiao, A., Ott, H. K., \& Bortree, D. (2017). Calling all volunteers: The role of stewardship and involvement in volunteer-organization relationships. Public Relations Review, 43(4), 872-881.

History. (n.d.). ACLU. Retrieved from https://www.history.com/topics/aclu

Holden, D. (2016). The ACLU couldn't keep up with everyone trying to donate after Trump won. BuzzFeed News.

Holloway, C. (2015). The ACLU's betrayal of civil liberties. The Witherspoon Institute. Retrieved from http://www.thepublicdiscourse.com/2015/03/14701/

Hsu, T. (2020). Corporate Voices Get Behind 'Black Lives Matter' Cause. The New York Times. Retrieved from https://www.nytimes.com/2020/05/31/business/media/companiesmarketing-black-lives-matter-george-floyd.html

Independent Sector. (2004). Statement of Values and Code of Ethics for Nonprofit and Philanthropic Organizations. Retrieved from http://www.ncdsv.org/images/stmtofvaludescodeethics.pdf

International Refugee Assistance Program (IRAP) v. Trump, 857 F. 3d 554 
$4^{\text {th }}$ Cir. (2017)

Johns Hopkins. (2020). COVID-19 Dashboard by the Center for Systems Science and Engineering (CSSE) at Johns Hopkins. Retrieved from https://gisanddata.maps.arcgis.com/apps/opsdashboard/index.html\#/bda7594740fd40299 $\underline{423467 \mathrm{~b} 48 \mathrm{e} 9 \mathrm{ecf} 6}$

Johnstone, L. (2016). The Republicans opposing Donald Trump - and voting for Hillary Clinton. NBC News.

Kiousis, S. \& Strömbäck, J. (2014). Political Public Relations. Handbook of Communication Sciences Volume 18: Political Communication. Berlin, Germany: Mouton de Gruyter.

Lamothe, M., \& Lavastida, V. (2020). Nonprofit Advocacy in the Era of Trump, Nonprofit Policy Forum, 11(3), 20200018. doi: https://doi.org/10.1515/npf-2020-0018

Martin, P.S. (2004). Inside the black box of negative campaign effects: Three reasons why negative campaigns mobilize. Political Psychology, 25(4).

Martinelli \& Mucciarone. (2007). New Deal public relations: A glimpse into FDR press secretary Steven Early's work. Public Relations Review. 33(1).

Morris, J. S., \& Francia, P. L. (2010). Cable news, public opinion, and the 2004 party conventions. Political Research Quarterly, 63(4), 834-849.

Mueller, R. S., \& United States. Department of Justice. Special Counsel's Office. (2019). Report on the investigation into Russian interference in the 2016 presidential election: submitted pursuant to 28 c.f.r. $§ 600.8$ (c) ([Redacted version]). U.S. Department of Justice.

Myers, M., \& Lariscy, R. (2013). Commercial speech, protected speech, and political public relations. Public Relations Review, 39(4), 332-332.

Neuborne, B. (2012). 'Why the ACLU is wrong about Citizens United.' The Nation.

Newman, B.J., Shah, S., \& Collingwood, C. (2018). Race, place and building a base: Latino population growth and the nascent Trump campaign for president, Public Opinion Quarterly, 82(1).

Nguyen, C. and Kebede, M. (2017). Immigrant students in the Trump era: What we know and do not know. Educational Policy, 31(6).

Nyren, E. (2017). Bill O'Reilly's most shocking quotes: The hoodie, ACLU terrorists and victim-blaming. Variety. 
O’Neil, J. (2007). The link between strong public relationships and donor support. Public Relations Review, 33(1), 99-102.

O'Reilly, L. (2017). The 84 Lumber Super Bowl ad's creative director explains the thinking behind the Mexican immigration-themed spot. Business Insider. Retrieved from https://www.businessinsider.com/84-lumber-super-bowl-ad-explained-2017-2

Panagopoulos, C. (2008). Partisan and nonpartisan message content and voter mobilization: Field experiment evidence. Political Research Quarterly, 62(1). 70-76.

Pew Research Center. (2020). Americans' views of government: Low trust, but some positive performance ratings. Retrieved from https://www.pewresearch.org/politics/2020/09/14/americans-views-of-government-lowtrust-but-some-positive-performance-ratings/

Pew Research Center. (2010). Section 6: Tea Party and Views of Government Overreach. Retrieved from: https://www.pewresearch.org/politics/2010/04/18/section-6tea-party-and-views-of-government-overreach/

Pyle, A. S., Linvill, D. L., \& Gennett, S. P. (2017). From silence to condemnation: Institutional responses to "travel ban" Executive Order 13769. Public Relations Review.

RealClear Politics. (n.d.) General Election: Trump vs. Clinton vs. Johnson vs. Stein. Retrieved from https://www.realclearpolitics.com/epolls/2016/president/us/general_election_trump_vs_cl inton_vs_johnson_vs_stein-5952.html

R.I.L-R v. Johnson, 80 F. Supp. 3d 164, 2015 U.S. Dist. LEXIS 20441 (D.D.C. February 20, 2015)

Romero, A.D. (2016). Donald Trump: A one man Constitutional crisis. Medium.

Romero, A.D. (2017). What does nonpartisanship look like in the age of Trump? ACLU. Retrieved from https://web.archive.org/web/20170317193104/https:/www.aclu.org/blog/speakfreely/what-does-nonpartisanship-look-age-trump

Romero, A.D. \& Rozanski, G.E. (2017). A revamped ACLU takes on today's fights. Stanford Social Innovation Review. Summer 2017, 15(3).

Rowland, L. (2017). Donald Trump has Free Speech Rights, Too. ACLU. Retrieved from https://web.archive.org/web/20170423080457/https:/www.aclu.org/blog/speakfreely/donald-trump-has-free-speech-rights-too 
Schreier, M. (2014). Qualitative content analysis. The SAGE Handbook of Qualitative Data Analysis. (pp. 170-183). 55 City Road, London: SAGE Publications, Inc. doi: 10.4135/9781446282243.n12

Seltzer, T. \& Zhang, W. (2010). Toward a model of political organization-public relationships: Antecedent and cultivation strategy influence on citizens' relationships with political parties. Journal of Public Relations Research, 23(1), 24-45.

Sierra Club Foundation. (n.d.). About the Sierra Club Foundation. Retrieved from https://www.sierraclubfoundation.org/about-scf

Sisson, D. C. (2017). Control mutuality, social media, and organization-public relationships: A study of local animal welfare organizations' donors. Public Relations Review, 43(1), 179-189.

Stack, L. (2017). Donations to A.C.L.U. and other organizations surge after Trump's order. The New York Times.

Sweetser, K. D., English, K., \& Fernandes, J. (2015). Super PACs and strong relationships: The impact of digital interaction on the political organization-public relationship. Journal of Public Relations Research, 27(2), 101-117.

Wilkins, D. B. (1995). Race, ethics, and the first amendment: Should black lawyer represent the Ku Klux Klan. George Washington Law Review, 63(6), 1030-1070.

Young, D. R. (2012).Government Failure Theory. In J.S. Ott \& L.A. Dicke (Ed.), The Nature of the Nonprofit Sector (pp.151-153). Boulder, Colorado: Westview Press 


\section{APPENDIX A: Breakdown of Data Available and Data Analyzed}

Bush Era: Jan. 20, 2001-Jan. 20, 2009

\begin{tabular}{|l|l|l|l|}
\hline Month & Year & Code & $\begin{array}{l}\text { "Snapshots" per } \\
\text { month }\end{array}$ \\
\hline September & 2000 & Election Years & $0 / 30$ \\
\hline October & 2000 & Election Years & $3 / 31$ \\
\hline November & 2000 & Election Years & $1 / 30$ \\
\hline February & 2001 & Inauguration Year & $3 / 28$ \\
\hline March & 2001 & Inauguration Year & $4 / 31$ \\
\hline April & 2001 & Inauguration Year & $1 / 30$ \\
\hline September & 2004 & Election Years & $29 / 30$ \\
\hline October & 2004 & Election Years & $14 / 31$ \\
\hline November & 2004 & Election Years & $21 / 30$ \\
\hline February & 2005 & Inauguration Year & $26 / 28$ \\
\hline March & 2005 & Inauguration Year & $29 / 31$ \\
\hline April & 2005 & Inauguration Year & $22 / 30$ \\
\hline January 31-July 6 & 2007 & ACLU v. NSA & $34 / 159$ \\
\hline & & & \\
\hline & & TOTAL & 187 \\
\hline
\end{tabular}

Obama Era: Jan. 20, 2009-Jan. 20, 2017

\begin{tabular}{|l|l|l|l|}
\hline Month & Year & Code & $\begin{array}{l}\text { "Snapshots" per } \\
\text { month }\end{array}$ \\
\hline September & 2008 & Election Years & $14 / 30$ \\
\hline October & 2008 & Election Years & $14 / 31$ \\
\hline November & 2008 & Election Years & $13 / 30$ \\
\hline February & 2009 & Inauguration Year & $6 / 28$ \\
\hline March & 2009 & Inauguration Year & $9 / 31$ \\
\hline April & 2009 & Inauguration Year & $8 / 30$ \\
\hline September & 2012 & Election Years & $25 / 30$ \\
\hline October & 2012 & Election Years & $18 / 31$ \\
\hline November & 2012 & Election Years & $18 / 30$ \\
\hline February & 2013 & Inauguration Year & $16 / 28$ \\
\hline March & 2013 & Inauguration Year & $17 / 31$ \\
\hline April & 2013 & Inauguration Year & $20 / 30$ \\
\hline $\begin{array}{l}\text { Dec. 16, 2014-Aug. 6, } \\
2015\end{array}$ & $2014 / 2015$ & R.I.L.-R. v. Johnson & $177 / 235$ \\
\hline & & & \\
\hline
\end{tabular}




\begin{tabular}{|l|l|l|l|}
\hline & & $\begin{array}{l}\text { TOTAL } \\
\text { SNAPSHOTS: }\end{array}$ & 355 \\
\hline
\end{tabular}

Trump Era: Jan. 20, 2017-present

\begin{tabular}{|l|l|l|l|}
\hline Month & Year & Code & $\begin{array}{l}\text { "Snapshots" per } \\
\text { month }\end{array}$ \\
\hline September & 2016 & Election Years & $21 / 30$ \\
\hline October & 2016 & Election Years & $19 / 31$ \\
\hline November & 2016 & Election Years & $27 / 30$ \\
\hline February & 2017 & Inauguration Year & $28 / 28$ \\
\hline March & 2017 & Inauguration Year & $30 / 31$ \\
\hline April & 2017 & Inauguration Year & $27 / 30$ \\
\hline Jan. 28-Aug. 31 & 2017 & Darweesh v. Trump & $210 / 216$ \\
\hline & & & \\
\hline & & $\begin{array}{l}\text { TOTAL } \\
\text { SNAPSHOTS: }\end{array}$ & 362 \\
\hline
\end{tabular}

The graphic (right) depicts all of the dates chosen for analysis and their timeframe (i.e., election year, inauguration year or during a time period where the ACLU was actively suing the U.S. government). Both Coder 1 and Coder 2 analyzed all highlighted dates to check for initial intercoder reliability.

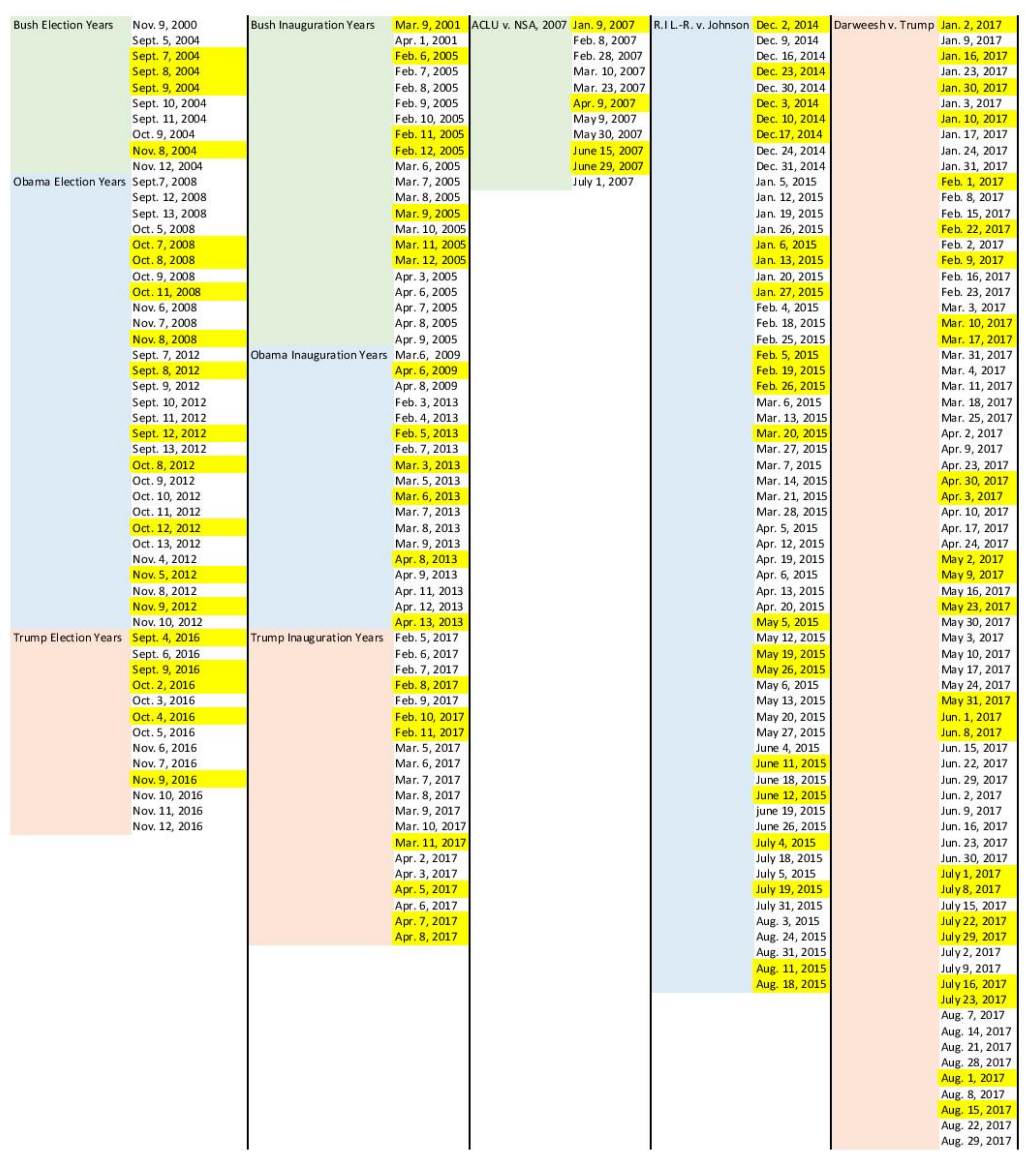




\section{APPENDIX B: ACLU Homepage Codebook}

This study seeks to understand how the ACLU has used and is currently using partisan rhetoric toward U.S. presidents and their administrations using the Wayback Machine archives. The Wayback Machine archive for the ACLU homepage can be located at http://web.archive.org/web/20170515000000*/www.aclu.org or by searching "www.aclu.org" through their search engine.

There are some important things to note while performing the content analysis:

1) The Wayback Machine has limited archives the further back one goes. For example, there may be no archives in February 1997.

2) In some instances there may be multiple archive snapshots in a given day. This is more common in the more recent years. In these examples, click on the first snapshot for that day.

3) Do not click on any links while on the homepage. This analysis is only concerned with what is listed on the homepage, as these are the organization's priorities and what they want to highlight. However, if the homepage features a scrolling list of articles or images, these are to be counted as being on the homepage.

Specific details about the coding form's questions are detailed below.

1) Coding Date (please indicate the date in which this document is being analyzed)

2) Coder Name

3) Date of document: (month, date, year format)

4) Category (Election year, inauguration year or a time when the ACLU sued the U.S. government)

5) President of the United States at this time (Bill Clinton: January 20 1993-January 20 2001; George W. Bush: January 20, 2001-January 20, 2009; Barack Obama: January 20, 2009-January 20, 2017; Donald Trump: January 20, 2016-present)

6) Are there any references to the presidents or presidents-elect above (i.e., Bill Clinton, George W. Bush, Barack Obama or Donald Trump) or any references to "the president" mentioned on the page (please specify which presidents are referenced)

7) If yes, how many times is his/their name (or references to "the president") listed? (Count ALL instances in headlines, images (not pictures of him, only his name in images) and ONCE per article (this includes the headline if applicable). For example, if an article is about the Bush administration's immigration policy, and he is mentioned by name three times in the article, only count President Bush's name once for this code.) 
8) If yes, are the references negative (please specify toward which president)? (Do you perceive the reference as negative? Negative language may include, but is not limited to: general disagreement with the individual; accusatory rhetoric; insults to character, appearance, intelligence, etc.; implications that the person is not qualified for the position; statements that the individual or their policy is wrong; references to unconstitutionality, etc.)

9) If yes, how many times is he referenced on the page in a negative way? (Again, count all instances in headlines, images (not pictures of him, only his name in images) and ONCE per article (this includes the headline if applicable).)

10) Please copy and paste any compelling examples of negative or partisan language here, if there are any:

11) Image of any of the four presidents present (if multiple images are referenced, please specify which ones) (Images may include photographs or cartoons/drawing of the president)

12) If yes, how many images of them are present? (Include all instances of an image of him being present. For example, if an article on the homepage features two images of President Obama, then count them both; however, only count it as one image per cartoon.)

13) Do you perceive any of the images as being negative toward them? If yes, please specify which president.(Do you perceive it as negative? Negative imagery can include, but is not limited to: purposefully unflattering photos, altered images that portray the president doing something illegal or wrong; cartoons poking fun/insulting the president, etc.)

14) Please screenshot and paste any compelling examples of negative or partisan imagery here, if there are any.

15) Is at least one member of the political party not in power mentioned (with the exception of Presidents Clinton, Bush, Obama and Trump)? (This question seeks to understand if the ACLU is biased toward one party over another. If there are people mentioned that you don't know who they are or which party they belong to, there is no need to look them up. Only use those that you know off hand belong to the party not in power for this question.)

16) If yes, are there any negative references to that person/that group of people? (Again, this is based on your judgment of what is negative.)

17) If yes, how many times is this group referenced in a negative way? (Similar to the question counting negative remarks about the president, count all instances in headlines, images (not pictures, only names in images) and ONCE per article (this includes the headline if applicable). For example, if an article talks about Attorney 
General William Barr and Secretary of Education Betsy DeVos, only count this as one negative reference. If they are each mentioned in a separate article, then count it as two.)

18) Did the ACLU acknowledge any partisanship in any of their messages? (An example of this may be something like "we don't normally endorse candidates, but..." or "while we don't typically attack political parties...")

19) Of all the instances of negative messaging or imagery toward the president or his administration, which of the following topics are they in reference to (circle all that apply) (These categories are not mutually exclusive, so circle any that apply. For example, if an article were about President Trump's policies on immigrant rights to safe abortions, then you would circle both 1 - Abortion and 9 - Immigration. Circle all that apply on a single homepage. If you are confused about which category the reference falls under, circle 24 - other and describe the reference. Also, "his administration" refers to those working in the federal executive branch/his cabinet. A member of the U.S. Senate, for example, would not count.)

20) Notes (if any): (Here you can share anything that you thought was noteworthy or different. You may share exact quotes or memo how the article made you feel. Was there anything that you think would be significant for how the ACLU is using partisanship?) 


\section{APPENDIX C: Coding Form}

1) Coding Date:

2) Coder Name:

3) Date of document:

4) Category:

1 Election Year (Sept.-Nov. 2000, 2004, 2008, 2012 and 2016)

2 Inauguration Year (Feb.-April 2001, 2005, 2009, 2013 and 2017)

3 Time period when the ACLU sued the U.S. government (January 31-July 6, 2007; Dec. 16, 2014-Aug. 6, 2015; Jan. 28-Aug. 31, 2017)

5) President of the United States at this time:

1 Bill Clinton, Democrat

2 George W. Bush, Republican

3 Barack Obama, Democrat

4 Donald Trump, Republican

6) Are there any references to the presidents or presidents-elect above (i.e., Bill Clinton, George W. Bush, Barack Obama or Donald Trump) or any references to "the president" mentioned on the page (please specify which presidents are referenced):

1 Yes

2 No

7) If yes, how many times is his/their name (or references to "the president") listed?

8) If yes, are any of the references negative (please specify toward which president)?
1 Yes
2 No
3 Unsure

9) If yes, how many times is he referenced on the page in a negative way?

10) Please copy and paste any compelling examples of negative or partisan language here, if there are any:

11) Image of any of the four presidents present (if multiple presidents are referenced, please specify which ones):

$\begin{array}{ll}1 & \text { Yes } \\ 2 & \text { No }\end{array}$

12) If yes, how many images of them are present? 
13) Do you perceive any of the images of them as being negative toward them? If yes, please specify which president:
1 Yes
2 No
3 Unsure

14) Please screenshot and paste any compelling examples of negative or partisan imagery here, if there are any:

15) Is at least one member of the political party not in power mentioned (with the exception of Presidents Clinton, Bush, Obama and Trump)?
1 Yes
2 No
3 Unsure

16) If yes, are there any negative references to that person/that group of people?
1 Yes
2 No
3 Unsure

17) If yes, how many times is this group referenced in a negative way?

18) Did the ACLU acknowledge any partisanship in any of their messages?
1 Yes
2 No
3 Unsure

19) Of all the instances of negative messaging or imagery toward the president or his administration, which of the following topics are they in reference to (circle all that apply):

1 Abortion

2 Children's rights

3 Death penalty/capital punishment

4 Euthanasia

5 Free Speech

6 Government surveillance

7 Gun rights

8 Healthcare

9 Immigration

10 Incarceration and/or police issues

11 Military

12 Native American rights

13 Press

14 Privacy

15 Property rights

16 Race relations 
17 Religion

18 Right to assemble/protesting

19 Right to due process

20 Right to marry/LGBTQ rights

21 Right to vote/voter suppression

22 Terrorism

23 Torture

24 Transgender rights

25 Women's rights, gender rights or feminism

26 Other (please specify)

20) Notes (if any): 


\section{APPENDIX D: Intercoder Reliability}

The following questions were analyzed in SPSS using Cohen's kappa to determine intercoder reliability:

Question 8: If yes, are any of the references [toward the president] negative (please specify toward which president)? (1 Yes, 2 No, 3 Unsure)

\section{Statistics}

difference

\begin{tabular}{llr} 
N & Valid & 89 \\
\cline { 2 - 3 } & Missing & 0 \\
\hline
\end{tabular}

\section{difference}

\begin{tabular}{|c|c|c|c|c|c|}
\hline & & & & & \\
\hline & & Frequency & Percent & Valid Percent & $\begin{array}{c}\text { Cumulative } \\
\text { Percent } \\
\end{array}$ \\
\hline Valid & -1.00 & 1 & 1.1 & 1.1 & 1.1 \\
\hline & .00 & 85 & 95.5 & 95.5 & 96.6 \\
\hline & 1.00 & 1 & 1.1 & 1.1 & 97.8 \\
\hline & 2.00 & 1 & 1.1 & 1.1 & 98.9 \\
\hline & 3.00 & 1 & 1.1 & 1.1 & 100.0 \\
\hline & Total & 89 & 100.0 & 100.0 & \\
\hline
\end{tabular}

\section{Case Processing Summary}

\begin{tabular}{|c|c|c|c|c|c|c|}
\hline & \multicolumn{6}{|c|}{ Cases } \\
\hline & \multicolumn{2}{|c|}{ Valid } & \multicolumn{2}{|c|}{ Missing } & \multicolumn{2}{|c|}{ Total } \\
\hline & $\mathrm{N}$ & Percent & $\mathrm{N}$ & Percent & $\mathrm{N}$ & Percent \\
\hline Coder $2 *$ Coder 1 & 89 & $100.0 \%$ & 0 & $0.0 \%$ & 89 & $100.0 \%$ \\
\hline
\end{tabular}

\section{Coder2 * Coder1 Crosstabulation}

\begin{tabular}{|c|c|c|c|c|c|c|c|}
\hline & & & \multicolumn{4}{|c|}{ Coder 1} & \multirow[b]{2}{*}{ Total } \\
\hline & & & Not applicable & Yes & No & Unsure & \\
\hline \multirow[t]{7}{*}{ Coder2 } & Not applicable & Count & 27 & 1 & 1 & 1 & 30 \\
\hline & & Expected Count & 9.1 & 15.2 & 4.7 & 1.0 & 30.0 \\
\hline & Yes & Count & 0 & 43 & 0 & 0 & 43 \\
\hline & & Expected Count & 13.0 & 21.7 & 6.8 & 1.4 & 43.0 \\
\hline & No & Count & 0 & 1 & 13 & 0 & 14 \\
\hline & & Expected Count & 4.2 & 7.1 & 2.2 & .5 & 14.0 \\
\hline & Unsure & Count & 0 & 0 & 0 & 2 & 2 \\
\hline
\end{tabular}




\begin{tabular}{l|l|r|r|r|r|r}
\hline & Expected Count & .6 & 1.0 & .3 & .1 & 2.0 \\
\hline \multirow{2}{*}{ Total } & Count & 27 & 45 & 14 & 3 & 89 \\
\cline { 2 - 7 } & Expected Count & 27.0 & 45.0 & 14.0 & 3.0 & 89.0 \\
\hline
\end{tabular}

\begin{tabular}{|c|c|c|c|c|c|}
\hline \multicolumn{6}{|c|}{ Symmetric Measures } \\
\hline & & Value & $\begin{array}{c}\text { Asymptotic } \\
\text { Standard Error }^{\mathrm{a}} \\
\end{array}$ & Approximate $\mathrm{T}^{\mathrm{b}}$ & $\begin{array}{l}\text { Approximate } \\
\text { Significance } \\
\end{array}$ \\
\hline Measure of Agreement & Kappa & .928 & .035 & 12.436 & .000 \\
\hline $\mathrm{N}$ of Valid Cases & & 89 & & & \\
\hline
\end{tabular}

a. Not assuming the null hypothesis.

b. Using the asymptotic standard error assuming the null hypothesis.

The coders had a $95.50 \%$ agreement and a kappa value of .928 for this question, so it was used for analysis in this study.

Question 9: If yes, how many times is he [the president] referenced on the page in a negative way?

\section{Statistics}

\begin{tabular}{|c|c|c|c|c|c|}
\hline \multicolumn{2}{|c|}{ difference } & \multirow[b]{2}{*}{89} & & & \\
\hline \multirow[t]{2}{*}{$\mathrm{N}$} & Valid & & & & \\
\hline & Missing & \multicolumn{2}{|c|}{0} & & \\
\hline \multicolumn{6}{|c|}{ difference } \\
\hline & & & & & Cumulative \\
\hline & & Frequency & Percent & Valid Percent & Percent \\
\hline \multirow[t]{6}{*}{ Valid } & -2.00 & 1 & 1.1 & 1.1 & 1.1 \\
\hline & -1.00 & 1 & 1.1 & 1.1 & 2.2 \\
\hline & .00 & 81 & 91.0 & 91.0 & 93.3 \\
\hline & 1.00 & 5 & 5.6 & 5.6 & 98.9 \\
\hline & 2.00 & 1 & 1.1 & 1.1 & 100.0 \\
\hline & Total & 89 & 100.0 & 100.0 & \\
\hline
\end{tabular}

\section{Case Processing Summary}

\begin{tabular}{|c|c|c|c|c|c|c|}
\hline & \multicolumn{6}{|c|}{ Cases } \\
\hline & \multicolumn{2}{|c|}{ Valid } & \multicolumn{2}{|c|}{ Missing } & \multicolumn{2}{|c|}{ Total } \\
\hline & $\mathrm{N}$ & Percent & $\mathrm{N}$ & Percent & $\mathrm{N}$ & Percent \\
\hline Coder $2 *$ Coder 1 & 89 & $100.0 \%$ & 0 & $0.0 \%$ & 89 & $100.0 \%$ \\
\hline
\end{tabular}




\begin{tabular}{|c|c|c|c|c|c|c|c|c|c|c|c|}
\hline \multicolumn{12}{|c|}{ Coder2* Coder1 Crosstabulation } \\
\hline & & \multicolumn{9}{|c|}{ Coder1 } & \multirow{2}{*}{ Total } \\
\hline & & 0 & 1 & 2 & 3 & 4 & 5 & 6 & 7 & 8 & \\
\hline \multirow{18}{*}{ Coder2 } & Count & 42 & 2 & 0 & 0 & 0 & 0 & 0 & 0 & 0 & 44 \\
\hline & $\begin{array}{l}{ }^{0} \text { Expected } \\
\text { Count }\end{array}$ & 20.8 & 5.9 & 3.5 & 5.4 & 4 & 1 & 2 & 1 & 0.5 & 44 \\
\hline & Count & 0 & 10 & 0 & 1 & 0 & 0 & 0 & 0 & 0 & 11 \\
\hline & $\begin{array}{l}1 \text { Expected } \\
\text { count }\end{array}$ & 5.2 & 1.5 & 0.9 & 1.4 & 1 & 0.2 & 0.5 & 0.2 & 0.1 & 11 \\
\hline & Count & 0 & 0 & 6 & 1 & 0 & 0 & 0 & 0 & 0 & 7 \\
\hline & $\begin{array}{l}2 \text { Expected } \\
\text { Count }\end{array}$ & 3.3 & 0.9 & 0.6 & 0.9 & 0.6 & 0.2 & 0.3 & 0.2 & 0.1 & 7 \\
\hline & Count & 0 & 0 & 1 & 9 & 1 & 0 & 0 & 0 & 0 & 11 \\
\hline & $\begin{array}{l}3 \text { Expected } \\
\text { Count }\end{array}$ & 5.2 & 1.5 & 0.9 & 1.4 & 1 & 0.2 & 0.5 & 0.2 & 0.1 & 11 \\
\hline & Count & 0 & 0 & 0 & 0 & 7 & 1 & 0 & 0 & 0 & 8 \\
\hline & $\begin{array}{l}4 \text { Expected } \\
\text { Count }\end{array}$ & 3.8 & 1.1 & 0.6 & 1 & 0.7 & 0.2 & 0.4 & 0.2 & 0.1 & 8 \\
\hline & Count & 0 & 0 & 0 & 0 & 0 & 1 & 0 & 0 & 0 & 1 \\
\hline & $\begin{array}{l}5 \text { Expected } \\
\text { Count }\end{array}$ & 0.5 & 0.1 & 0.1 & 0.1 & 0.1 & 0 & 0 & 0 & 0 & 1 \\
\hline & Count & 0 & 0 & 0 & 0 & 0 & 0 & 4 & 0 & 0 & 4 \\
\hline & $\begin{array}{l}6 \text { Expected } \\
\text { Count }\end{array}$ & 1.9 & 0.5 & 0.3 & 0.5 & 0.4 & 0.1 & 0.2 & 0.1 & 0 & 4 \\
\hline & Count & 0 & 0 & 0 & 0 & 0 & 0 & 0 & 2 & 0 & 2 \\
\hline & $\begin{array}{l}7 \text { Expected } \\
\text { Count }\end{array}$ & 0.9 & 0.3 & 0.2 & 0.2 & 0.2 & 0 & 0.1 & 0 & 0 & 2 \\
\hline & Count & 0 & 0 & 0 & 0 & 0 & 0 & 0 & 0 & 1 & 1 \\
\hline & $\begin{array}{l}10 \text { Expected } \\
\text { Count }\end{array}$ & 0.5 & 0.1 & 0.1 & 0.1 & 0.1 & 0 & 0 & 0 & 0 & 1 \\
\hline \multirow[b]{2}{*}{ Total } & Count & 42 & 12 & 7 & 11 & 8 & 2 & 4 & 2 & 1 & 89 \\
\hline & $\begin{array}{l}\text { Expected } \\
\text { Count }\end{array}$ & 42 & 12 & 7 & 11 & 8 & 2 & 4 & 2 & 1 & 89 \\
\hline
\end{tabular}

\section{Symmetric Measures}

\begin{tabular}{|c|c|c|c|c|c|}
\hline & & Value & $\begin{array}{c}\text { Asymptotic } \\
\text { Standard Error } \\
\end{array}$ & Approximate $\mathrm{T}^{\mathrm{b}}$ & $\begin{array}{l}\text { Approximate } \\
\text { Significance }\end{array}$ \\
\hline Measure of Agreement & Kappa & .875 & .041 & 16.698 & .000 \\
\hline $\mathrm{N}$ of Valid Cases & & 89 & & & \\
\hline
\end{tabular}

a. Not assuming the null hypothesis.

b. Using the asymptotic standard error assuming the null hypothesis.

The coders had a $91.01 \%$ agreement and a kappa value of .875 for this question, so it was used for analysis in this study.

Question 13: Do you perceive any of the images of them [Presidents Bush, Obama and/or Trump] as being negative toward them? If yes, please specify which president: (1 Yes, 2 No, 3 Unsure)

\section{Statistics}

difference

\begin{tabular}{llr} 
N & Valid & 89 \\
\cline { 2 - 3 } & Missing & 0 \\
\hline
\end{tabular}

\begin{tabular}{|c|c|c|c|c|c|}
\hline \multicolumn{6}{|c|}{ difference } \\
\hline & & Frequency & Percent & Valid Percent & $\begin{array}{c}\text { Cumulative } \\
\text { Percent }\end{array}$ \\
\hline Valid & -1.00 & 2 & 2.2 & 2.2 & 2.2 \\
\hline
\end{tabular}




\begin{tabular}{rr|r|r|r}
\hline .00 & 83 & 93.3 & 93.3 & 95.5 \\
\hline 1.00 & 1 & 1.1 & 1.1 & 96.6 \\
\hline 2.00 & 2 & 2.2 & 2.2 & 98.9 \\
\hline 3.00 & 1 & 1.1 & 1.1 & 100.0 \\
\hline Total & 89 & 100.0 & 100.0 & \\
\hline
\end{tabular}

\section{Case Processing Summary}

\begin{tabular}{|c|c|c|c|c|c|c|}
\hline & \multicolumn{6}{|c|}{ Cases } \\
\hline & \multicolumn{2}{|c|}{ Valid } & \multicolumn{2}{|c|}{ Missing } & \multicolumn{2}{|c|}{ Total } \\
\hline & $\mathrm{N}$ & Percent & $\mathrm{N}$ & Percent & $\mathrm{N}$ & Percent \\
\hline Coder $2 *$ Coder 1 & 89 & $100.0 \%$ & 0 & $0.0 \%$ & 89 & $100.0 \%$ \\
\hline
\end{tabular}

\section{Coder2 * Coder1 Crosstabulation}

\begin{tabular}{|c|c|c|c|c|c|c|c|}
\hline & & & \multicolumn{4}{|c|}{ Coder1 } & \multirow[b]{2}{*}{ Total } \\
\hline & & & Not applicable & Yes & No & Unsure & \\
\hline \multirow[t]{6}{*}{ Coder2 } & Not applicable & Count & 60 & 1 & 2 & 1 & 64 \\
\hline & & Expected Count & 43.1 & 9.3 & 10.8 & .7 & 64.0 \\
\hline & Yes & Count & 0 & 10 & 0 & 0 & 10 \\
\hline & & Expected Count & 6.7 & 1.5 & 1.7 & .1 & 10.0 \\
\hline & No & Count & 0 & 2 & 13 & 0 & 15 \\
\hline & & Expected Count & 10.1 & 2.2 & 2.5 & .2 & 15.0 \\
\hline \multirow[t]{2}{*}{ Total } & & Count & 60 & 13 & 15 & 1 & 89 \\
\hline & & Expected Count & 60.0 & 13.0 & 15.0 & 1.0 & 89.0 \\
\hline
\end{tabular}

Symmetric Measures

\begin{tabular}{|c|c|c|c|c|c|}
\hline \multicolumn{6}{|c|}{ symiction } \\
\hline & & Value & $\begin{array}{c}\text { Asymptotic } \\
\text { Standard Error } \\
\end{array}$ & Approximate $\mathrm{T}^{\mathrm{b}}$ & $\begin{array}{l}\text { Approximate } \\
\text { Significance }\end{array}$ \\
\hline Measure of Agreement & Kappa & .857 & .055 & 10.937 & .000 \\
\hline $\mathrm{N}$ of Valid Cases & & 89 & & & \\
\hline
\end{tabular}

a. Not assuming the null hypothesis.

b. Using the asymptotic standard error assuming the null hypothesis.

The coders had a 93.29\% agreement and a kappa value of .857 for this question, so it was used for analysis in this study.

Question 17: If yes, how many times is this group [members of the political party not in power] referenced in a negative way?

\section{Statistics}

difference 


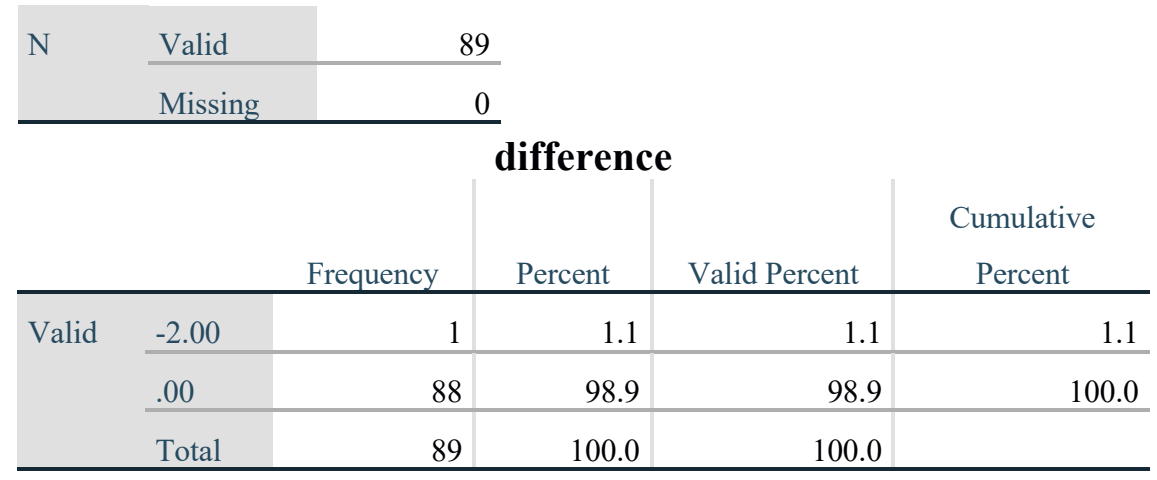

\section{Case Processing Summary}

\begin{tabular}{|c|c|c|c|c|c|c|}
\hline & \multicolumn{6}{|c|}{ Cases } \\
\hline & \multicolumn{2}{|c|}{ Valid } & \multicolumn{2}{|c|}{ Missing } & \multicolumn{2}{|c|}{ Total } \\
\hline & $\mathrm{N}$ & Percent & $\mathrm{N}$ & Percent & $\mathrm{N}$ & Percent \\
\hline Coder $2 *$ Coder 1 & 89 & $100.0 \%$ & 0 & $0.0 \%$ & 89 & $100.0 \%$ \\
\hline
\end{tabular}

\section{Coder 2 * Coder1 Crosstabulation}

\begin{tabular}{|c|c|c|c|c|c|}
\hline & & & \multicolumn{2}{|c|}{ Coder 1} & \multirow[b]{2}{*}{ Total } \\
\hline & & & 0 & 1 & \\
\hline \multirow[t]{6}{*}{ Coder 2} & 0 & Count & 87 & 0 & 87 \\
\hline & & Expected Count & 86.0 & 1.0 & 87.0 \\
\hline & 1 & Count & 0 & 1 & 1 \\
\hline & & Expected Count & 1.0 & .0 & 1.0 \\
\hline & 2 & Count & 1 & 0 & 1 \\
\hline & & Expected Count & 1.0 & .0 & 1.0 \\
\hline \multirow[t]{2}{*}{ Total } & & Count & 88 & 1 & 89 \\
\hline & & Expected Count & 88.0 & 1.0 & 89.0 \\
\hline
\end{tabular}

\section{Symmetric Measures}

\begin{tabular}{|c|c|c|c|c|c|}
\hline \multicolumn{6}{|c|}{ ה.20 } \\
\hline & & & Asymptotic & & Approximate \\
\hline & & Value & Standard Error ${ }^{\mathrm{a}}$ & Approximate $\mathrm{T}^{\mathrm{b}}$ & Significance \\
\hline Measure of Agreement & Kappa & .663 & .315 & 8.428 & .000 \\
\hline $\mathrm{N}$ of Valid Cases & & 89 & & & \\
\hline
\end{tabular}

a. Not assuming the null hypothesis.

b. Using the asymptotic standard error assuming the null hypothesis.

While the two coders strongly agreed on this question ( $98.87 \%$ agreement), the kappa value of .663 did not meet the required value to be deemed agreeable not just by chance. Because of this kappa value, this question was not used in analysis; however, it is worth noting that there were not many examples of people outside of the president's political party being mentioned at all. 
Question 18: Did the ACLU acknowledge any partisanship in any of their messages? (1 Yes, 2 No, 3 Unsure)

Cohen's kappa could not be mathematically calculated as one of the coders found that there were no instances of acknowledging partisanship (i.e., they answered 2 for every document analyzed). The second coder's results were similar but not identical. Since there were no good examples of the ACLU mentioning partisanship on their homepage, this question was dropped from the analysis. 
APPENDIX E: Breakdown of Civil Liberties Issues Referenced When the ACLU Spoke Negatively about the President

\begin{tabular}{|c|c|c|c|c|c|c|}
\hline & \multicolumn{3}{|c|}{$\begin{array}{l}\text { PRESIDENT BUSH BREAKDOWN: } \\
\text { PERCENTAGE OF TOPICS } \\
\text { NEGATIVELY DISCUSSED }\end{array}$} & \multirow[b]{2}{*}{$\begin{array}{l}\text { Obama } \\
\text { Election } \\
\text { Years }(28 \\
\text { docs) }\end{array}$} & \multirow[b]{2}{*}{$\begin{array}{l}\text { Obama } \\
\text { Inauguration } \\
\text { Years }(18 \\
\text { docs) }\end{array}$} & \multirow[b]{2}{*}{$\begin{array}{l}\text { R.I.L.-R. v. } \\
\text { Johnson } \\
\text { (62 docs) }\end{array}$} \\
\hline & $\begin{array}{l}\text { Election } \\
\text { Years }(9 \\
\text { docs) }\end{array}$ & $\begin{array}{l}\text { Inauguration } \\
\text { Years }(21 \\
\text { docs) }\end{array}$ & $\begin{array}{l}A C L U v . \\
N S A(11 \\
\operatorname{docs})\end{array}$ & & & \\
\hline 1 Abortion & $0.00 \%$ & $0.00 \%$ & $0.00 \%$ & $3.57 \%$ & $0.00 \%$ & $0.00 \%$ \\
\hline $\begin{array}{l}2 \text { Children's } \\
\text { rights }\end{array}$ & $0.00 \%$ & $0.00 \%$ & $0.00 \%$ & $0.00 \%$ & $0.00 \%$ & $0.00 \%$ \\
\hline $\begin{array}{l}3 \quad \text { Death } \\
\text { penalty/capital } \\
\text { punishment }\end{array}$ & $0.00 \%$ & $0.00 \%$ & $0.00 \%$ & $0.00 \%$ & $0.00 \%$ & $0.00 \%$ \\
\hline $4 \quad$ Euthanasia & $0.00 \%$ & $0.00 \%$ & $0.00 \%$ & $0.00 \%$ & $0.00 \%$ & $0.00 \%$ \\
\hline $\begin{array}{ll}5 & \text { Free Speech }\end{array}$ & $0.00 \%$ & $0.00 \%$ & $18.18 \%$ & $0.00 \%$ & $0.00 \%$ & $0.00 \%$ \\
\hline $\begin{array}{l}6 \text { Government } \\
\text { surveillance }\end{array}$ & $0.00 \%$ & $9.50 \%$ & $27.27 \%$ & $0.00 \%$ & $0.00 \%$ & $0.00 \%$ \\
\hline $\begin{array}{ll}7 & \text { Gun rights }\end{array}$ & $0.00 \%$ & $0.00 \%$ & $0.00 \%$ & $0.00 \%$ & $0.00 \%$ & $0.00 \%$ \\
\hline 8 Healthcare & $0.00 \%$ & $0.00 \%$ & $0.00 \%$ & $3.57 \%$ & $5.56 \%$ & $0.00 \%$ \\
\hline 9 Immigration & $0.00 \%$ & $0.00 \%$ & $0.00 \%$ & $0.00 \%$ & $0.00 \%$ & $0.00 \%$ \\
\hline $\begin{array}{l}10 \text { Incarceration } \\
\text { and/or police } \\
\text { issues }\end{array}$ & $0.00 \%$ & $0.00 \%$ & $9.09 \%$ & $0.00 \%$ & $0.00 \%$ & $0.00 \%$ \\
\hline 11 Military & $0.00 \%$ & $0.00 \%$ & $0.00 \%$ & $0.00 \%$ & $0.00 \%$ & $0.00 \%$ \\
\hline $\begin{array}{l}12 \text { Native } \\
\text { American rights }\end{array}$ & $0.00 \%$ & $0.00 \%$ & $0.00 \%$ & $0.00 \%$ & $0.00 \%$ & $0.00 \%$ \\
\hline 13 Press & $0.00 \%$ & $0.00 \%$ & $0.00 \%$ & $0.00 \%$ & $0.00 \%$ & $0.00 \%$ \\
\hline 14 Privacy & $0.00 \%$ & $0.00 \%$ & $36.36 \%$ & $0.00 \%$ & $0.00 \%$ & $0.00 \%$ \\
\hline $\begin{array}{l}15 \text { Property } \\
\text { rights }\end{array}$ & $0.00 \%$ & $0.00 \%$ & $0.00 \%$ & $0.00 \%$ & $0.00 \%$ & $0.00 \%$ \\
\hline $\begin{array}{l}16 \text { Race } \\
\text { relations }\end{array}$ & $0.00 \%$ & $0.00 \%$ & $0.00 \%$ & $0.00 \%$ & $0.00 \%$ & $0.00 \%$ \\
\hline 17 Religion & $0.00 \%$ & $0.00 \%$ & $9.09 \%$ & $0.00 \%$ & $0.00 \%$ & $1.61 \%$ \\
\hline $\begin{array}{l}18 \text { Right to } \\
\text { assemble/protesti } \\
\text { ng }\end{array}$ & $0.00 \%$ & $0.00 \%$ & $0.00 \%$ & $0.00 \%$ & $0.00 \%$ & $0.00 \%$ \\
\hline $\begin{array}{l}19 \text { Right to due } \\
\text { process }\end{array}$ & $0.00 \%$ & $0.00 \%$ & $0.00 \%$ & $0.00 \%$ & $0.00 \%$ & $0.00 \%$ \\
\hline $\begin{array}{l}20 \text { Right to } \\
\text { marry/LGBTQ } \\
\text { rights }\end{array}$ & $0.00 \%$ & $0.00 \%$ & $0.00 \%$ & $0.00 \%$ & $0.00 \%$ & $0.00 \%$ \\
\hline $\begin{array}{l}21 \text { Right to } \\
\text { vote/voter } \\
\text { suppression }\end{array}$ & $0.00 \%$ & $0.00 \%$ & $0.00 \%$ & $0.00 \%$ & $0.00 \%$ & $0.00 \%$ \\
\hline 22 Terrorism & $0.00 \%$ & $0.00 \%$ & $0.00 \%$ & $0.00 \%$ & $0.00 \%$ & $0.00 \%$ \\
\hline 23 Torture & $0.00 \%$ & $0.00 \%$ & $0.00 \%$ & $10.71 \%$ & $0.00 \%$ & $4.84 \%$ \\
\hline
\end{tabular}




\begin{tabular}{|l|l|l|l|l|l|l|}
\hline $\begin{array}{l}\text { 24 Transgender } \\
\text { rights }\end{array}$ & $0.00 \%$ & $0.00 \%$ & $0.00 \%$ & $0.00 \%$ & $0.00 \%$ & $0.00 \%$ \\
\hline $\begin{array}{l}\mathbf{2 5} \text { Women's } \\
\text { rights, gender } \\
\text { rights or } \\
\text { feminism }\end{array}$ & $0.00 \%$ & $0.00 \%$ & $0.00 \%$ & $0.00 \%$ & $0.00 \%$ & $0.00 \%$ \\
\hline $\begin{array}{l}\text { 26 Other (please } \\
\text { specify) }\end{array}$ & $33.33 \%$ & $0.00 \%$ & $18.18 \%$ & $3.57 \%$ & $11.11 \%$ & $1.61 \%$ \\
\hline $\begin{array}{l}\text { \# of days the } \\
\text { ACLU spoke } \\
\text { negatively about } \\
\text { Pres. }\end{array}$ & $\begin{array}{l}3 \text { days } \\
(33.33 \%)\end{array}$ & 2 days $(9.5 \%)$ & $\begin{array}{l}6 \text { days } \\
(54.55 \%)\end{array}$ & $\begin{array}{l}3 \text { days } \\
(10.71 \%)\end{array}$ & 1 day $(5.56 \%)$ & $\begin{array}{l}3 \text { days } \\
(4.84 \%)\end{array}$ \\
\hline
\end{tabular}

\begin{tabular}{|c|c|c|c|c|c|c|}
\hline & \multicolumn{4}{|c|}{$\begin{array}{l}\text { PRESIDENT OBAMA BREAKDOWN: } \\
\text { PERCENTAGE OF TOPICS NEGATIVELY } \\
\text { DISCUSSED }\end{array}$} & \multirow[b]{2}{*}{$\begin{array}{l}\text { Trump } \\
\text { Inauguration } \\
\text { Years (19 } \\
\text { docs) }\end{array}$} & \multirow[b]{2}{*}{$\begin{array}{l}\text { Darweesh } \\
\text { v. Trump } \\
\text { (72 docs) }\end{array}$} \\
\hline & $\begin{array}{l}\text { Election } \\
\text { Years }(28 \\
\text { docs) }\end{array}$ & $\begin{array}{l}\text { Inauguratio } \\
\text { n Years (18 } \\
\text { docs) }\end{array}$ & $\begin{array}{l}\text { R.I.L.-R. v. } \\
\text { Johnson (62 } \\
\text { docs) }\end{array}$ & $\begin{array}{l}\text { Trump } \\
\text { Election } \\
\text { Years }(13 \\
\text { docs) } \\
\end{array}$ & & \\
\hline $1 \quad$ Abortion & $0.00 \%$ & $0.00 \%$ & $0.00 \%$ & $0.00 \%$ & $0.00 \%$ & $0.00 \%$ \\
\hline $\begin{array}{l}2 \text { Children's } \\
\text { rights }\end{array}$ & $0.00 \%$ & $0.00 \%$ & $0.00 \%$ & $0.00 \%$ & $0.00 \%$ & $0.00 \%$ \\
\hline $\begin{array}{l}3 \quad \text { Death } \\
\text { penalty/capital } \\
\text { punishment }\end{array}$ & $0.00 \%$ & $0.00 \%$ & $0.00 \%$ & $0.00 \%$ & $0.00 \%$ & $0.00 \%$ \\
\hline $4 \quad$ Euthanasia & $0.00 \%$ & $0.00 \%$ & $0.00 \%$ & $0.00 \%$ & $0.00 \%$ & $0.00 \%$ \\
\hline $\begin{array}{ll}5 & \text { Free Speech }\end{array}$ & $0.00 \%$ & $0.00 \%$ & $0.00 \%$ & $0.00 \%$ & $0.00 \%$ & $0.00 \%$ \\
\hline $\begin{array}{lc}6 & \text { Government } \\
\text { surveillance }\end{array}$ & $0.00 \%$ & $0.00 \%$ & $0.00 \%$ & $0.00 \%$ & $0.00 \%$ & $0.00 \%$ \\
\hline $\begin{array}{ll}7 & \text { Gun rights } \\
\end{array}$ & $0.00 \%$ & $0.00 \%$ & $0.00 \%$ & $0.00 \%$ & $0.00 \%$ & $0.00 \%$ \\
\hline 8 Healthcare & $0.00 \%$ & $0.00 \%$ & $0.00 \%$ & $0.00 \%$ & $0.00 \%$ & $0.00 \%$ \\
\hline 9 Immigration & $0.00 \%$ & $0.00 \%$ & $9.68 \%$ & $0.00 \%$ & $0.00 \%$ & $0.00 \%$ \\
\hline $\begin{array}{l}\text { 10 Incarceration } \\
\text { and/or police } \\
\text { issues }\end{array}$ & $0.00 \%$ & $0.00 \%$ & $4.84 \%$ & $0.00 \%$ & $0.00 \%$ & $0.00 \%$ \\
\hline 11 Military & $0.00 \%$ & $0.00 \%$ & $0.00 \%$ & $0.00 \%$ & $5.26 \%$ & $2.78 \%$ \\
\hline $\begin{array}{l}12 \text { Native } \\
\text { American rights }\end{array}$ & $0.00 \%$ & $0.00 \%$ & $0.00 \%$ & $0.00 \%$ & $0.00 \%$ & $0.00 \%$ \\
\hline 13 Press & $0.00 \%$ & $0.00 \%$ & $0.00 \%$ & $0.00 \%$ & $0.00 \%$ & $0.00 \%$ \\
\hline 14 Privacy & $0.00 \%$ & $0.00 \%$ & $0.00 \%$ & $0.00 \%$ & $0.00 \%$ & $0.00 \%$ \\
\hline $\begin{array}{l}15 \text { Property } \\
\text { rights }\end{array}$ & $0.00 \%$ & $0.00 \%$ & $0.00 \%$ & $0.00 \%$ & $0.00 \%$ & $0.00 \%$ \\
\hline $\begin{array}{l}16 \text { Race } \\
\text { relations }\end{array}$ & $0.00 \%$ & $0.00 \%$ & $0.00 \%$ & $0.00 \%$ & $0.00 \%$ & $0.00 \%$ \\
\hline 17 Religion & $0.00 \%$ & $0.00 \%$ & $0.00 \%$ & $0.00 \%$ & $0.00 \%$ & $0.00 \%$ \\
\hline $\begin{array}{l}18 \text { Right to } \\
\text { assemble/protesti } \\
\text { ng }\end{array}$ & $0.00 \%$ & $0.00 \%$ & $0.00 \%$ & $0.00 \%$ & $0.00 \%$ & $0.00 \%$ \\
\hline $\begin{array}{l}19 \text { Right to due } \\
\text { process }\end{array}$ & $0.00 \%$ & $0.00 \%$ & $0.00 \%$ & $0.00 \%$ & $0.00 \%$ & $0.00 \%$ \\
\hline
\end{tabular}




\begin{tabular}{|l|l|l|l|l|l|l|}
\hline $\begin{array}{l}\mathbf{2 0} \text { Right to } \\
\text { marry/LGBTQ } \\
\text { rights }\end{array}$ & $0.00 \%$ & $0.00 \%$ & $0.00 \%$ & $0.00 \%$ & $0.00 \%$ & $0.00 \%$ \\
\hline $\begin{array}{l}\mathbf{2 1} \text { Right to } \\
\text { vote/voter } \\
\text { suppression }\end{array}$ & $0.00 \%$ & $0.00 \%$ & $0.00 \%$ & $0.00 \%$ & $0.00 \%$ & $0.00 \%$ \\
\hline $\mathbf{2 2}$ Terrorism & $0.00 \%$ & $0.00 \%$ & $0.00 \%$ & $0.00 \%$ & $0.00 \%$ & $0.00 \%$ \\
\hline $\mathbf{2 3}$ Torture & $0.00 \%$ & $0.00 \%$ & $1.61 \%$ & $0.00 \%$ & $0.00 \%$ & $0.00 \%$ \\
\hline $\begin{array}{l}\mathbf{2 4} \text { Transgender } \\
\text { rights }\end{array}$ & $0.00 \%$ & $0.00 \%$ & $0.00 \%$ & $0.00 \%$ & $0.00 \%$ & $0.00 \%$ \\
\hline $\begin{array}{l}\mathbf{2 5} \text { Women's } \\
\text { rights, gender } \\
\text { rights or } \\
\text { feminism }\end{array}$ & $0.00 \%$ & $0.00 \%$ & $0.00 \%$ & $0.00 \%$ & $0.00 \%$ & $0.00 \%$ \\
\hline $\begin{array}{l}\mathbf{2 6} \text { Other (please } \\
\text { specify) }\end{array}$ & $0.00 \%$ & $0.00 \%$ & $4.84 \%$ & $0.00 \%$ & $0.00 \%$ & $0.00 \%$ \\
\hline $\begin{array}{l}\text { \# of days the } \\
\text { ACLU spoke } \\
\text { negatively about } \\
\text { Pres. }\end{array}$ & 0 days & $\begin{array}{l}0 \text { days } \\
(0.00 \%)\end{array}$ & $\begin{array}{l}9 \text { days } \\
(14.52 \%)\end{array}$ & $\begin{array}{l}0 \text { days } \\
(0.00 \%)\end{array}$ & 1 day (5.26) & $\begin{array}{l}2 \text { days } \\
(2.78 \%)\end{array}$ \\
\hline
\end{tabular}

\begin{tabular}{|c|c|c|c|}
\hline & \multicolumn{3}{|c|}{$\begin{array}{l}\text { PRESIDENT TRUMP BREAKDOWN: PERCENTAGE OF TOPICS } \\
\text { NEGATIVELY DISCUSSED }\end{array}$} \\
\hline & $\begin{array}{l}\text { Trump Election } \\
\text { Years (13 docs) }\end{array}$ & $\begin{array}{l}\text { Trump Inauguration } \\
\text { Years (19 docs) }\end{array}$ & $\begin{array}{l}\text { Darweesh v. Trump } \\
\text { (72 docs) }\end{array}$ \\
\hline 1 Abortion & $0.00 \%$ & $0.00 \%$ & $4.17 \%$ \\
\hline 2 Children's rights & $0.00 \%$ & $0.00 \%$ & $0.00 \%$ \\
\hline $\begin{array}{l}3 \text { Death penalty/capital } \\
\text { punishment }\end{array}$ & $0.00 \%$ & $0.00 \%$ & $0.00 \%$ \\
\hline $4 \quad$ Euthanasia & $0.00 \%$ & $0.00 \%$ & $0.00 \%$ \\
\hline $\begin{array}{ll}5 & \text { Free Speech }\end{array}$ & $0.00 \%$ & $0.00 \%$ & $4.17 \%$ \\
\hline $\begin{array}{ll}6 & \text { Government surveillance }\end{array}$ & $0.00 \%$ & $15.79 \%$ & $0.00 \%$ \\
\hline $\begin{array}{ll}7 & \text { Gun rights }\end{array}$ & $0.00 \%$ & $0.00 \%$ & $0.00 \%$ \\
\hline 8 Healthcare & $0.00 \%$ & $0.00 \%$ & $22.22 \%$ \\
\hline 9 Immigration & $0.00 \%$ & $100 \%$ & $51.39 \%$ \\
\hline $\begin{array}{l}10 \text { Incarceration and/or police } \\
\text { issues }\end{array}$ & $0.00 \%$ & $21.05 \%$ & $13.89 \%$ \\
\hline 11 Military & $0.00 \%$ & $5.26 \%$ & $15.28 \%$ \\
\hline 12 Native American rights & $0.00 \%$ & $0.00 \%$ & $0.00 \%$ \\
\hline 13 Press & $0.00 \%$ & $0.00 \%$ & $0.00 \%$ \\
\hline 14 Privacy & $0.00 \%$ & $0.00 \%$ & $4.17 \%$ \\
\hline 15 Property rights & $0.00 \%$ & $0.00 \%$ & $0.00 \%$ \\
\hline 16 Race relations & $0.00 \%$ & $0.00 \%$ & $6.94 \%$ \\
\hline 17 Religion & $0.00 \%$ & $63.16 \%$ & $37.50 \%$ \\
\hline 18 Right to assemble/protesting & $0.00 \%$ & $0.00 \%$ & $0.00 \%$ \\
\hline 19 Right to due process & $0.00 \%$ & $0.00 \%$ & $0.00 \%$ \\
\hline
\end{tabular}




\begin{tabular}{|l|l|l|l|}
\hline $\begin{array}{l}\mathbf{2 0} \text { Right to marry/LGBTQ } \\
\text { rights }\end{array}$ & $0.00 \%$ & $47.37 \%$ & $15.28 \%$ \\
\hline $\begin{array}{l}\mathbf{2 1} \text { Right to vote/voter } \\
\text { suppression }\end{array}$ & $0.00 \%$ & $0.00 \%$ & $22.22 \%$ \\
\hline $\mathbf{2 2}$ Terrorism & $0.00 \%$ & $0.00 \%$ & $0.00 \%$ \\
\hline $\mathbf{2 3}$ Torture & $0.00 \%$ & $31.58 \%$ & $4.17 \%$ \\
\hline $\mathbf{2 4}$ Transgender rights & $0.00 \%$ & $0.00 \%$ & $0.00 \%$ \\
\hline $\begin{array}{l}\mathbf{2 5} \text { Women's rights, gender } \\
\text { rights or feminism }\end{array}$ & $0.00 \%$ & $31.58 \%$ & $6.94 \%$ \\
\hline $\mathbf{2 6}$ Other (please specify) & $30.77 \%$ & $94.74 \%$ & $65.28 \%$ \\
\hline $\begin{array}{l}\text { \# of days the ACLU spoke } \\
\text { negatively about Pres. }\end{array}$ & 4 days (30.77\%) & 19 days (100\%) & 70 days $(97.22 \%)$ \\
\hline
\end{tabular}




\section{APPENDIX F: ACLU Mission Statement}

\section{THE ACLU TODAY}

For nearly 100 years, the ACLU has been our nation's guardian of liberty, working in courts, legislatures, and communities to defend and preserve the individual rights and liberties that the Constitution and the laws of the United States guarantee everyone in this country.

Whether it's achieving full equality for LGBT people, establishing new privacy protections for our digital age of widespread government surveillance, ending mass incarceration, or preserving the right to vote or the right to have an abortion, the ACLU takes up the toughest civil liberties cases and issues to defend all people from government abuse and overreach.

With more than 2 million members, activists, and supporters, the ACLU is a nationwide organization that fights tirelessly in all 50 states, Puerto Rico, and Washington, D.C., to safeguard everyone's rights.

\section{IN THE BEGINNING}

"So long as we have enough people in this country willing to fight for their rights, we'll be called a democracy." - ACLU founder Roger Baldwin

When a roomful of civil liberties activists - led by Roger Baldwin, Crystal Eastman, and Albert DeSilver - formed the ACLU in 1920, the Supreme Court had yet to uphold a single free speech claim. Activists languished in jail for distributing anti-war literature. State-sanctioned violence against African-Americans was routine. Women won the right to vote only in August of that year. And constitutional rights for LGBT people were unthinkable.

The ACLU was founded to ensure the promise of the Bill of Rights and to expand its reach to people historically denied its protections. In our first year, we fought the harassment and deportation of immigrants whose activism put them at odds with the authorities. In 1939, we won in the Supreme Court the right for unions to organize. We stood almost alone in 1942 in denouncing our government's round-up and internment in concentration camps of more than 110,000 Japanese-Americans. And at times in our history when frightened civilians have been willing to give up some of their freedoms and rights in the name of national security, the ACLU has been the bulwark for liberty.

\section{WHY WE DO WHAT WE DO}

The ACLU is frequently asked to explain its defense of certain people or groups - particularly controversial and unpopular entities such as the Ku Klux Klan, the Nation of Islam, and the National Socialist Party of America. We do not defend them because we agree with them. Rather we defend their right to free expression and free assembly.

Historically, the people whose opinions are the most controversial or extreme are the people whose rights are most often threatened. Once the government has the power to violate one person's rights, it can use that power against everyone. We work to stop the erosion of civil liberties before it's too late. 


\section{HOW WE DO IT}

We have grown from a roomful of civil libertarians to more than 1 million members, activists, and supporters across the country. The ACLU is now a nationwide organization with a 50-state network of staffed affiliate offices filing cases in both state and federal courts. We appear before the Supreme Court more than any other organization except the Department of Justice.

In addition, we work to change policy as well as hearts and minds. Our Washington Legislative Office lobbies Congress to pass bills that advance or defend civil liberties and defeat those that do not, our affiliates work in state houses across the country to do the same, and we use strategic communications to engage supporters on the most pressing civil liberties issues of our time. The defense of America's core liberties cannot rely on the courts alone. Politics and public opinion matter too.

The ACLU is nonprofit and nonpartisan. We do not receive any government funding. Member dues as well as contributions and grants from private foundations and individuals pay for the work we do.

If you wish to join the ACLU, or you believe your civil liberties have been violated, contact ACLU headquarters (https://www.aclu.org/contact-us) or your local ACLU (https://www.aclu.org/affiliates). 


\section{APPENDIX G: The Independent Sector's Statement of Values and Code of Ethics for Nonprofit and Philanthropic Organizations}

\section{Statement of Values}

Any code of ethics is built on a foundation of widely shared values. The values of the independent sector include:

- Commitment to the public good;

- Accountability to the public;

- Commitment beyond the law;

- Respect for the worth and dignity of individuals;

- Inclusiveness and social justice;

- Respect for pluralism and diversity

- Transparency, integrity and honesty;

- Responsible stewardship of resources; and,

- Commitment to excellence and to maintaining the public trust.

These values lead directly to the Code of Ethics for Nonprofit and Philanthropic Organizations that follows. The values inform and guide the actions that organizations should take in developing their policies and informing their practices.

\section{The Code of Ethics for Nonprofit and Philanthropic Organizations}

\section{Personal and Professional Integrity}

All staff, board members and volunteers of the organization act with honesty, integrity and openness in all their dealings as representatives of the organization. The organization promotes a working environment that values respect, fairness and integrity.

\section{Mission}

The organization has a clearly stated mission and purpose, approved by the board of directors, in pursuit of the public good. All of its programs support that mission and all who work for or on behalf of the organization understand and are loyal to that mission and purpose. The mission is responsive to the constituency and communities served by the organization and of value to the society at large.

\section{Governance}

The organization has an active governing body that is responsible for setting the mission and strategic direction of the organization and oversight of the finances, operations, and policies of the organization. The governing body:

- Ensures that its board members or trustees have the requisite skills and experience to carry out their duties and that all members understand and fulfill their governance duties acting for the benefit of the organization and its public purpose;

- Has a conflict of interest policy that ensures that any conflicts of interest or the appearance thereof are avoided or appropriately managed through disclosure, recusal or other means; and

- Is responsible for the hiring, firing, and regular review of the performance of the chief executive officer, and ensures that the compensation of the chief executive officer is reasonable and appropriate; 
- Ensures that the CEO and appropriate staff provide the governing body with timely and comprehensive information so that the governing body can effectively carry out its duties;

- Ensures that the organization conducts all transactions and dealings with integrity and honesty;

- Ensures that the organization promotes working relationships with board members, staff, volunteers, and program beneficiaries that are based on mutual respect, fairness and openness;

- Ensures that the organization is fair and inclusive in its hiring and promotion policies and practices for all board, staff and volunteer positions;

- Ensures that policies of the organization are in writing, clearly articulated and officially adopted;

- Ensures that the resources of the organization are responsibly and prudently managed; and,

- Ensures that the organization has the capacity to carry out its programs effectively.

\section{Legal Compliance}

The organization is knowledgeable of and complies with all laws, regulations and applicable international conventions.

\section{Responsible Stewardship}

The organization and its subsidiaries manage their funds responsibly and prudently. This should include the following considerations:

- It spends a reasonable percentage of its annual budget on programs in pursuance of its mission;

- It spends an adequate amount on administrative expenses to ensure effective accounting systems, internal controls, competent staff, and other expenditures critical to professional management;

- The organization compensates staff, and any others who may receive compensation, reasonably and appropriately;

- Organizations that solicit funds have reasonable fundraising costs, recognizing the variety of factors that affect fundraising costs;

- Organizations do not accumulate operating funds excessively;

- Organizations with endowments (both foundations and public charities) prudently draw from endowment funds consistent with donor intent and to support the public purpose of the organization;

- Organizations ensure that all spending practices and policies are fair, reasonable and appropriate to fulfill the mission of the organization; and,

- All financial reports are factually accurate and complete in all material respects.

\section{Openness and Disclosure}

The organization provides comprehensive and timely information to the public, the media, and all stakeholders and is responsive in a timely manner to reasonable requests for information. All information about the organization will fully and honestly reflect the policies and practices of the organization. Basic informational data about the organization, such as the Form 990, reviews and compilations, and audited financial statements will be posted on the organization's website or 
otherwise available to the public. All solicitation materials accurately represent the organization's policies and practices and will reflect the dignity of program beneficiaries. All financial, organizational, and program reports will be complete and accurate in all material respects.

\section{Program Evaluation}

The organization regularly reviews program effectiveness and has mechanisms to incorporate lessons learned into future programs. The organization is committed to improving program and organizational effectiveness and develops mechanisms to promote learning from its activities and the field. The organization is responsive to changes in its field of activity and is responsive to the needs of its constituencies.

\section{Inclusiveness and Diversity}

The organization has a policy of promoting inclusiveness and its staff, board and volunteers reflect diversity in order to enrich its programmatic effectiveness. The organization takes meaningful steps to promote inclusiveness in its hiring, retention, promotion, board recruitment and constituencies served.

\section{Fundraising}

Organizations that raise funds from the public or from donor institutions are truthful in their solicitation materials. Organizations respect the privacy concerns of individual donors and expend funds consistent with donor intent. Organizations disclose important and relevant information to potential donors.

In raising funds from the public, organizations will respect the rights of donors, as follows:

- To be informed of the mission of the organization, the way the resources will be used and their capacity to use donations effectively for their intended purposes;

- To be informed of the identity of those serving on the organization's governing board and to expect the board to exercise prudent judgment in its stewardship responsibilities;

- To have access to the organization's most recent financial reports;

- To be assured their gifts will be used for the purposes for which they were given;

- To receive appropriate acknowledgement and recognition;

- To be assured that information about their donations is handled with respect and with confidentiality to the extent provided by the law;

- To expect that all relationships with individuals representing organizations of interest to the donor will be professional in nature;

- To be informed whether those seeking donations are volunteers, employees of the organizations or hired solicitors;

- To have the opportunity for their names to be deleted from mailing lists that an organization may intend to share; and,

- To feel free to ask questions when making a donation and to receive prompt, truthful and forthright answers.

\section{Grantmaker Guidelines}

Organizations that are grantmakers have particular responsibilities in carrying out their missions. These include the following: 
- They will have constructive relations with grantseekers based on mutual respect and shared goals;

- They will communicate clearly and on a timely basis with potential grantees;

- They will treat grantseekers and grantees fairly and with respect;

- They will respect the expertise of grantseekers in their fields of knowledge;

- They will seek to understand and respect the organizational capacity and needs of grantseeking organizations; and,

- They will respect the integrity of the mission of grantseeking organizations. 